\title{
Gaming innovation ecosystem: actors, roles and co-innovation processes
}

\section{Patrycja Klimas $^{1}$ (D) $\cdot$ Wojciech Czakon ${ }^{2}$}

Received: 28 May 2021 / Accepted: 1 January 2022 / Published online: 8 March 2022

(c) The Author(s) 2022

\begin{abstract}
Burgeoning research on innovation ecosystems offers a variety of conceptual approaches. Recent systematic literature reviews and syntheses provide a rich, diverse, but somehow abstract view of IEs. Our study advances the literature by taking the perspective of those involved in IEs. We aim to identify how various actors contribute to co-innovation in innovation ecosystems. In order to do so, our aim is to establish the various types of actors (who?), the distinct roles (what?), the different stages (when?), and the diverse engagement in co-innovation processes (how?). The study investigates the Polish Gaming Innovation Ecosystem as a globally successful example of a knowledge-intensive and highly creative innovation ecosystem. Data was collected over 3 years (between 2015 and 2017), in three waves of interviews (38) and non-participatory observations (5). We find that Gaming Innovation Ecosystem participants identify a total of 12 types of collective actors, 9 types of individual actors, and 1 community of individuals. Furthermore, we find four distinctive roles that actors may play in the co-creation processes, that is: direct value creation, supporting value creation, encouraging entrepreneurship, and leadership. Finally, we structure the co-innovation process into five stages: co-discovery, co-development, co-deployment, co-delivery and co-dissemination. We identify the diverse scope and varied intensity of actors' engagement, depending on the co-innovation phase, as perceived by our informants.
\end{abstract}

Keywords Co-innovation · Ecosystems $\cdot$ Co-creation $\cdot$ Game development $\cdot$ Gaming industry $\cdot$ NPD

Patrycja Klimas

patrycja.klimas@ue.wroc.pl

Wojciech Czakon

wojciech.czakon@uj.edu.pl

1 Department of Advanced Research in Management, Wroclaw University of Economics and Business, Komandorska, 118/120, 53-345 Wrocław, Poland

2 Strategic Management Department, Jagiellonian University, Łojasiewicza 4, 30-348 Kraków, Poland 
JEL Classification L14 $\cdot \mathrm{L} 82 \cdot \mathrm{O} 36$

\section{Introduction}

Ecosystems (Adner 2017; Tsujimoto et al. 2018), and innovation ecosystems (IE) in particular (Durst and Poutanen 2013; Yaghmaie and Vanhaverbeke, 2019; Talmar et al. 2018; Adner 2017; Aarikka-Stenroos and Ritala 2017), are attracting a rapidly growing attention in both academia and managerial practice (Vargo et al. 2015; Thomas and Autio 2020). Typically for nascent fields, scholars underline the harmful conceptual shortcomings regarding the definition of ecosystems (Granstrand and Holgersson 2020; Klimas and Czakon 2022; Scott et al. 2021; Tsujimoto et al. 2018), blurry conceptualizations (Aarikka-Stenroos and Ritala 2017; Oh et al. 2016), or the deficit of operationalizations (Ritala and Almpanopoulou 2017). Several gaps in the current understanding of ecosystems (Bouncken and Kraus 2021; Thomas and Autio 2020) are widened by rapid changes in the business environment, growing uncertainty (Bouncken and Kraus 2021), and increasing openness to both cooperation and coopetition (Zhang and Watson 2020). Additionally, it is also quite common to find different terms for the same type of ecosystems, the same term for different ones, or no distinction between various types of ecosystems despite fundamental differences (de Gomes et al. 2018; Pattinson et al. 2018).

According to the ecosystem perspective, every type of ecosystem is directly focused on value co-creation (Aarikka-Stenroos and Ritala 2017; Kapoor and Lee 2013; Vargo et al. 2015). However, co-creation is driven by different processes in different types of ecosystems e.g. knowledge co-creation in knowledge ecosystems, innovation co-creation in innovation ecosystems, or co-creation of new business ventures in entrepreneurial ecosystems. In contrast to networks or alliances, joint value creation in ecosystems does not necessarily involve explicit rules of value capture (Bouncken et al. 2020). Importantly, in ecosystems a multi-actor approach is adopted (Adner 2017; Pilinkiene and Maciulis 2014; Bacon and Williams 2021), as opposed to actor-to-actor orientation in value co-creation, transcending the classic dyadic (Vargo and Lusch 2011) linear, sequential approach to joint value creation (Vargo and Lusch 2004). Indeed in ecosystems, the co-creation with customers (Prahalad and Ramaswamy 2004) and even of communities with customers (Prahalad 2004), goes much further by involving co-creation with other external actors, and even entire networks of actors (Vargo and Lusch 2011).

Recent literature points to IE as currently fastest growing thread of research (Dąbrowska et al. 2019; Granstrand and Holgersson 2020; Klimas and Czakon 2022), but it also points out conceptual inconsistencies (Durst and Poutanen 2013; Lin et al. 2018; Thomas and Autio 2020) and shortcomings (Oh et al. 2016; Ritala and Almpanopoulou 2017; Adner 2017). For instance, although the structural approach to IE acknowledges actors as constitutive components, there is no agreement regarding the types of relevant actors. Moreover, the ego-centric view focused mainly on the single most powerful actor dominates (e.g. Beliaeva et al. 2019; Dąbrowska et al. 2019), leaving other actors poorly recognized or characterized. Additionally, even though IE actors are acknowledged to play different roles 
within IEs (Dedehayir et al. 2016), and to be engaged in IEs activities to various degrees (Granstrand and Holgersson 2020), there is no coherent view on how this engagement can be differentiated e.g. among the focal and peripheral actors. Furthermore, while the literature on IE expresses the need for pooling innovation capabilities across the entire co-innovation process, the bulk of research attention is paid to innovation output, which leaves other phases of the co-innovation process unexplored (Klimas and Czakon 2022). To sum up, our study addresses the above shortcomings and the gaps stemming therefrom.

We aim to identify innovation ecosystems from the perspective of those engaged in innovation processes. Such perceptions are consequential because they have implications for behaviours, including actions aimed at others in the business environment or carried out collectively with others (Czakon and Czernek-Marszałek 2021). We aim to establish the various types of actors (who?), the distinct roles (what?), the different stages (when?), and the diverse engagement in co-innovation processes (how?) as perceived by those involved in innovation ecosystems.

We empirically ground both the structural (Granstrand and Holgersson 2020) and the dynamic (Bouncken and Kraus 2021) views on IEs, and develop a framework for mapping the actors, their roles and their degree of engagement in co-innovation processes. Our in-depth study focuses on the Gaming Innovation Ecosystem in Poland, a globally successful example of a knowledge-intensive and highly creative innovation ecosystem. We collected field data over 3 years (between 2015 and 2017) using triangulated data sources including non-participatory observations (5), structured (13) and semi-structured interviews (8 exploratory and 17 member-checks). Following a theory-driven, directed approach (Hsieh and Shannon 2005), we coded our data with deductive codes derived from the academic and grey literature to map the actors, their roles and their engagement in the co-innovation processes in their own perception. Then, we matched the theoretical and empirical patterns (Bouncken et al. 2021) in order to theorize from these rich insights.

Our findings support, extend and alter recent conceptual developments regarding the innovation ecosystem (Granstrand and Holgersson 2020; Klimas and Czakon 2022) using the structural perspective (Adner 2017). We provide a synthesis of the literature and an empirical list of the various actors involved in innovation ecosystems. We single out the various roles played in innovation ecosystems, and the relevant phases of co-innovation processes. We develop an empirically grounded, finegrained view on distinct roles and the involvement of actors in the five phases of the co-innovation process.

\section{Conceptual background}

The ecosystems approach emphasizes the strategic relevance of business surroundings in organizations' activities, which help firms in achieving a sustainable competitive advantage (Zhang and Watson 2020). Ecosystems are a way of seeing an organizations' environment (Sun et al. 2017), or as a useful way of operationalizing this environment (de Gomes et al. 2018). Compared to inter-organizational networks, ecosystems are more boundaryless (Durst and Poutanen 2013), but are not 
open-ended (Adner 2017). Ecosystems have boundaries within which organizations may thrive, and beyond which their immediate interest is much limited. Therefore, setting out ecosystems' boundaries is crucially important for conceptual rigor and clarity, but is also meaningful to those involved in their operations (Walrave et al. 2018), because the way an environment is perceived has implications for competitive and collaborative actions (Czakon and Czernek-Marszałek 2021). An ecosystem's boundaries can be identified using such criteria as: actor (Gawer and Cusumano 2014a), structure (Phillips and Srai 2018), the ecosystem's value proposition criterion (Walrave et al. 2018), geography (Aarikka-Stenroos and Ritala 2017; Mazzucato and Robinson 2018; Valkokari 2015), technology (Aarikka-Stenroos and Ritala 2017; Autio and Thomas, 2014), and product (Tsujimoto et al. 2018). Depending on the criterion adopted, ecosystems may be defined differently in terms of scope and structure. Therefore, a key challenge for the ecosystems stream of research relates to delineation criteria.

From the output perspective, two types of ecosystems are important due to their impact on technological development, product creation and growth (Bouncken and Kraus 2021): innovation and entrepreneurship ecosystems. Given the scarcity of empirical findings on innovation ecosystems, they still appear as an emerging concept requiring research (Adner 2017; Dąbrowska et al. 2019; Granstrand and Holgersson 2020; Klimas and Czakon 2022; Ritala and Almpanopoulou 2017; Thomas and Autio 2020; Yaghmaie and Vanhaverbeke 2019).

Innovation ecosystems are sets of "interdependent actors who combine specialized yet complementary resources and/or capabilities in seeking to (a) co-create and deliver an overarching value proposition to end-users, and (b) appropriate gains received in the process" (Walrave et al. 2018: 104). If actors are the constitutive component of any innovation ecosystem, defining an IE implies listing its participants. Surprisingly, the bulk of the literature takes an ego-centric approach, and the perspective of single actors, with either their direct or indirect innovation co-creative relationships with the firms responsible for the launch of innovation. Recent literature reviews clearly show that the pool of empirical works is limited, and innovation ecosystems "are characterized in most cases by a one-on-one relationship between the focal firm and its partner. Inter-organizational relations involving multiple partners are rather rare" (Yaghmaie and Vanhaverbeke 2019: 3). Such focus is increasingly seen as an impediment to the development of ecosystems understanding (Arora et al. 2019; Jucevičius and Grumadaitè 2014).

While the ego-centric perspective remains the most popular even in recent studies (Dąbrowska et al. 2019), scholars recognize the need to take a broader perspective (Klimas and Czakon 2022). Indeed, as pointed out by Granstrand and Holgersson (2020), innovation ecosystems can operate around one focal organization such as a hub firm, innovation orchestrator or anchor firm (Beliaeva et al. 2019; Dąbrowska et al. 2019), but also as eco-centric or operating around a few innovation leaders. In the same vein, Sun et al. (2019) indicate that innovation processes can be created and coordinated by one actor in a top-down approach, or emerge in a self-coordinated bottom-up way. Therefore, seeing IEs as "organized around a focal firm or a platform" (Autio and Tomas 2014: 3) seems to be too narrow, thus hampering conceptual developments (Arora et al. 2019; Jucevičius and Grumadaitė 
2014). Few notable studies approach innovation ecosystems as intentionally orchestrated and collectively coordinated by several actors (Holgersson et al. 2018; Song 2016). Therefore, innovation ecosystems are more accurately defined as a "cooperation environment surrounding the innovation activities of its co-evolving actors, organized across co-innovation processes, and resulting in co-creation of new value delivered through innovation" (Klimas and Czakon 2022: 6). Hence, IE conceptually differ from innovation alliances, which are focused on value co-creation through co-innovation processes. IEs may be focused on innovation-related value creation (Bouncken et al. 2020) through collaborative innovation or open innovation, but not necessarily co-innovation, in other words through open models of innovation (less complex and less open) other than co-innovation (Lee et al. 2012).

Due to the deficit of empirical investigation on eco-centric innovation ecosystems, our study focuses on the Gaming Innovation Ecosystem (GIE) operating around the video game industry (VGI), but not organized around a single focal video game developer (VGD).

\subsection{Gaming innovation ecosystems}

GIEs are non-egocentric innovation ecosystems operating around many actors, none of which is a leader, focal firm or ecosystem orchestrator. Examining them takes the entire gaming innovation ecosystem as the unit of analysis (Ritala and Almpanopoulou 2017). GIEs are complex, multidisciplinary, dynamic structures comprised of co-evolving actors cooperating under co-innovation processes to release innovative video games, thus providing gamers and players with a co-created value proposition. Following Mercan and Göktaş, GIEs "consist of economic agents and economic relations as well as the non-economic parts such as technology, institutions, sociological interactions, and the culture: (2016: 102) related to games and gaming.

In terms of the institutional framework developed by Granstrand and Holgersson (2020), a GIE covers a set of various and evolving actors (video game developers, gamers, game distributors, publishers, etc.), their activities (video game development processes, sale, promotional events, market research, etc.), artifacts (various video games, their improvements, patches, etc.), and the institutions and relationships, including complementary and substitute relationships (inter-organizational, interpersonal, inter-community, etc.), that are important for the innovative performance of an actor or a population of actors (Banks and Potts 2010)

\subsection{GIE actors}

This study focuses on the actors, processes and resources involved in generating intended ecosystem outputs, that is co-innovations (Lee et al. 2012). Additionally, the outputs are seen as a feature of innovation ecosystems that distinguish one from another (Aarikka-Stenroos and Ritala 2017; de Gomes et al. 2018; Ritala and Almpanopoulou 2017; Valkokari 2015).

GIE actors can be characterized as: (1) operating in a hyper-dynamic, technologically advanced and knowledge-intensive industry (Xu et al. 2018); (2) running a 
business in a fast-developing emerging industry that tightly links technology, art and business (Schmalz et al. 2014; Xu et al. 2018); (3) struggling with above-average uncertainty due to unilinear and unpredictable innovation development (Russell and Smorodinskaya 2018; Schmalz et al. 2014); (4) facing increasing and progressive digitalization (Oh et al. 2016), and (5) operating under high innovation and competitive pressure (Koch and Bierbamer 2016; Oh et al. 2016; Russell and Smorodinskaya 2018). Such environmental characteristics favour the creation of innovation ecosystems and encourage active participation in its activities.

An individual GIE consists of formal and informal organizations, individuals and communities of individuals interested, and engaged in co-innovation processes aimed at the development and release of new games. This multilateral structure is both complex and loose at the same time. On the one hand, the innovation ecosystem involves various types of actors targeting different main goals (e.g. developers $v s$ gamers) with differing interest in the co-creation of new value (e.g. developers $v s$ university). Moreover, these actors are connected through a set of dyadic, triadic and multi-actor relationships that take the form of innovation co-creation relationships, i.e. a type of co-creation relationship (Vargo 2009) aimed at the mutual realization of the innovation process, and thus exploited during the co-innovation process (Klimas 2019).

On the other hand, the innovation ecosystem is loose as the relationships among and between actors are usually exploited ad hoc and periodically in an informal way through social connections. Indeed, the development of video games runs cumulatively and it is hard to plan everything a priori, thus new product development processes are not only seen as risky, but uncertain as well (Schmalz et al. 2014). Additionally, the video game industry reflects typical features of the creative industry, including extraordinary uncertainty (Lingo and Tepper 2014), a high level of independent creativity (Tschang 2005), and favouring social relationships. "Video game developers can be understood as a unique social group called an occupational community" (Weststar 2015: 1238) strongly embedded in social relationships within the industry. Social relationships among developers are a significant source of value co-creation (Tschang 2007; Zackariasson and Wilson 2010), but social relationships with communities of users (Burger-Helmchen and Cohendet 2011; Parmentier and Mangematin 2014), communities of gamers (Marchand and Hennig-Thurau 2013), or communities of modders and hackers (Poor 2013) ${ }^{1}$ are also important for co-innovation.

\subsection{GIE co-innovation processes}

Under the "ecosystem of business, where individuals, organizations, governments, and economies are all networked and interdependent, we need a new innovation model" (Lee et al. 2012: 818). This most open form of innovation is co-innovation (Lee et al. 2012), i.e. a process in which external partners such as firms, institutes,

\footnotetext{
1 These specific types of gaming-related actors (e.g. different types of gamers, modders, testers, hackers, etc.) are characterized in detail in Table 1.
} 


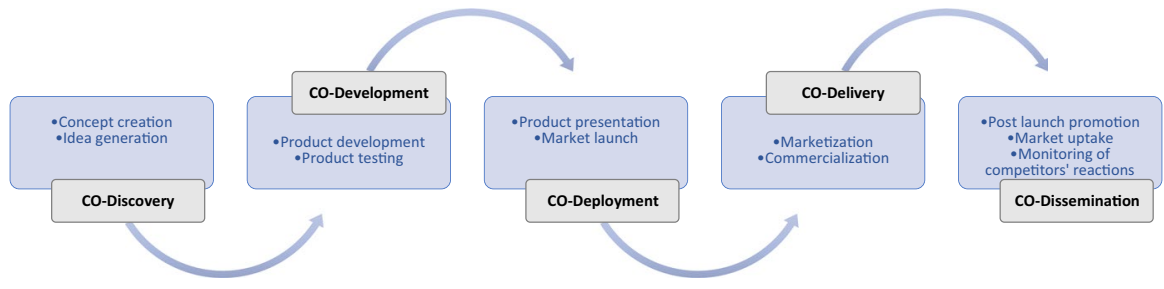

Fig. 1 The stages of the co-innovation process Source: own work using (Baregheh et al. 2009; Ernst et al. 2010; Hoyer et al. 2010; Klimas 2019; Krafft and Singh 2010; Song et al. 1998)

NGOs and customers are involved in the innovation effort through the sharing of knowledge, other resources, costs and benefits to create unique customer value (van Blokland et al. 2008). Co-innovation takes the form of interactive development (Bossink 2002), and therefore is a co-evolving process (Royer and Bijman 2009) based on ongoing convergence, collaboration and co-creation among actors (Lee et al. 2012). There is a gap in the ecosystems literature relative to the identification of actors involvement in subsequent stages of the co-innovation process. Some conceptual suggestions are available, but lack empirical examination. For instance, Autio and Thomas (2014) point to the discovery, development, deployment and delivery of new products or services. Klimas (2019) posits that co-innovation is a cooperative process covering: co-discovery, co-development, co-deployment and co-delivery of new products or services. Other relevant stages such as implementation (Ernst et al. 2020); adoption (Baregheh et al. 2009), post-launch (Hoyer et al. 2010), adjustments and diversification (Geissdoerfer et al. 2016) can be found in the new product development stream of literature. By integrating these propositions, we expand the 4-stage framework for the co-innovation process developed by Klimas (2019) by adding a process focused on innovation co-dissemination, as suggested in innovation management literature (Table III in Baregheh et al. (2009). Therefore, we see the process of co-innovation as consisting of five subsequent stages (Fig. 1): co-discovery i.e., ideation and concept design; co-development i.e., prototyping and production; co-deployment i.e., product implementation; co-delivery i.e., marketization and commercialization; and co-dissemination i.e., late promotion, adjustments and re-configurations.

\subsection{GIE outputs}

GIEs main outputs are games, which are the medium of value created, co-created, appropriated and delivered to customers. Video games are typically developed as projects deployed across the innovation process, so game releases can be seen as an innovation output. Video game designing leads to innovation output resulting from "creative processes such as insight or inspiration, or from the form of creativity that 'blends' disparate concepts together in novel ways by adapting, adding or combining them" (Tschang and Szczypula 2006: 470). Further on, bringing a game from concept to market" always takes the form of a project in terms of project management (Schmalz et al. 2014). Video game developers (VGDs) are project-based 
organizations (Legault and Weststar 2015). These project-based and innovation-oriented characteristics provide favourable conditions for the creation and development of a successful innovation ecosystem (Pombo-Juárez et al. 2017; Thomas and Autio 2020).

Video games can be characterized as: (1) integrated and highly modular products (Adner 2006); (2) complex and technologically advanced products (Dattee et al. 2018), (3) products based on several interdependent and complementary technologies (Holgersson et al. 2018), (4) products usually targeting new global demands and adopting new technological solutions (Ferasso et al. 2018), and (5) products with the potential to draw benefits from co-creation or co-development, also through relationships with communities of users (Autio and Thomas 2014; Russell and Smorodinskaya 2018; Niemand et al., 2021). These characteristics are important because they favour the creation of innovation ecosystems and encourage a wide range of actors to actively participate in co-innovation processes.

\section{Research design}

Our study aims to understand the innovation ecosystem from the perspective of those engaged in innovative processes. In line with managerial perception literature (Czakon and Czernek-Marszałek 2021), we rely on qualitative methods adequate for exploring the "what", "how", "when", "who" and "where" research questions (Gioia et al. 2013) where theory is unavailable, scant or nascent (Graebner et al. 2012). Accordingly, we address the following research questions: who creates IE, what are the distinct roles of the actors, how do these actors engage in the roles and stages, and when/where are these roles performed in terms of the stages of co-innovation processes.

\subsection{Empirical setting}

Prior innovation ecosystem studies have focused on various industries: design in Great Britain (Sunley et al. 2008), telecommunications in Germany (Rohrbeck et al. 2009), healthcare in the US (Kapoor and Lee, 2013), biofuel in the US (Weil et al. 2014), high-tech manufacturing in China (Wu et al. 2018; Xu et al. 2018), aerospace in the US (Mazzucato and Robinson 2018), and the global jewellery industry (Dąbrowska et al. 2019). We follow calls to investigate industries other than high-tech manufacturing (Kapoor and Furr 2015). We selected the video game industry as it is technologically advanced, knowledge-intensive and at the same time highly creative. It remains surprisingly underexplored in management research (Burger-Helmchen and Cohendet 2011; Mazzucato and Robinson 2018) including ecosystems research (Feijoó 2012; Inoue and Nagayama 2011; Klimas 2019).

We purposefully selected the Polish Gaming Innovation Ecosystem as a globally successful example of a knowledge-intensive and highly creative innovation ecosystem (according to reports by the Entertainment Software Association, Euromonitor 
International, NewZoo, the Polish Gamers Observatory and Statista). The main criterion used to select this GIE was the intensity of innovation, so the studied context provides a rich example for the study, but is not an extreme case (Suri 2011). The GIE is concentrated around the formal video game industry operating in Poland and covers the entire value (co-) creation processes, including various actors engaged across these processes such as video game developers, publishers, NGOs, gamers, players and different types of gaming communities. Also, video games, video game developers and the video game industry are quite novel industrial contexts in management research, including research on innovation ecosystems (Inoue and Tsujimoto 2017; Ozalp et al. 2018). Finally, prior studies on GIE were run in other national contexts (Inoue and Nagayama 2011), in GIE operating around global corporations (Inoue and Tsujimoto 2017; Ozalp et al. 2018), or were focused on mobile IE only (Feijoó 2012).

\subsection{Data collection}

To capture perceptions stable over time, we collected data over 3 years (from 2015 to 2017) in three waves of interviews (38) and non-participatory observations (5) with various actors involved in the GIE. We aimed to capture mutual perceptions and diverse views of the same focal GIE, including the view of the researchers through their observations. The general framework of the gaming innovation ecosystem was developed by reviewing prior systematic literature reviews (Czakon et al. 2019; Kraus et al. 2020).

To ensure the reliability and validity of our study (Humble 2009), five types of triangulation were used (Guion et al. 2011): data, investigator, theory, methodological, and context. Data was triangulated from two sources of data sources: secondary i.e., academic and grey literature including industry reports, industry and company websites, online forums and portals for game developers, gamers, game reviewers, etc. (Appendix 1); and primary, that is field research using structured interviews, two rounds of semi-structured interviews and non-participatory observations (Appendix 2). Investigator triangulation consisted in involving two researchers in the analytical process separately, then establishing convergent findings and discussing differences. Theory triangulation involved several theoretical views on co-innovation processes i.e., new product development, innovation ecosystems, and co-innovations. By mobilizing multiple analysis methods, i.e., deductive coding, thematic analysis, and flexible pattern matching we ensured methodological triangulation. Finally, by collecting data in different contextual settings: online and on-site in firms' headquarters, in neutral locations such as restaurants, and during trade fairs we ensured contextual triangulation. We reached out to individuals representing different industrial perspectives as key informants i.e., video game developers, publishers, a global consulting company and gaming media. Moreover, we run non-participatory observations during trade fairs (Game Industry Conference during Game Arena), B2B events (Digital Dragons and Mastering the Game), and game jams (organized by Digital Dragons Academy). 


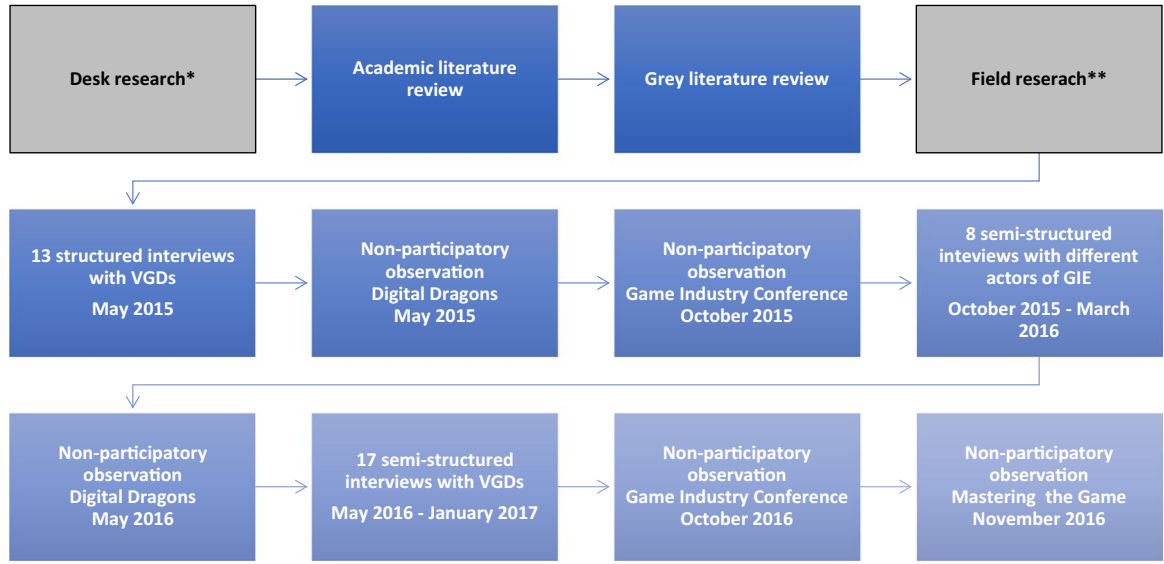

* The list of analyzed grey literature is presented in Appendix 1.

** Details are presented in Appendix 2.

Fig. 2 Data collection process

The research process (Fig. 2) consisted of a literature review (Appendix 1) and the empirical study. To collect data, we designed a long-term process starting in 2015 and finishing in 2017. This process covered two phases: one focused more on exploration and the second more on findings validation through member checks (Appendix 2).

Phase 1 involved three data collection techniques (Appendix 2): 13 structured interviews with VGDs attending Digital Dragons 2015 (May 2015); 8 semistructured, direct interviews with open questions covering sources of firm innovativeness and a wide range of co-creation relationships used to build, leverage or defend firm innovativeness and create new games (October 2015-March 2016); 5 non-participatory observations (May 2015-November 2016) focused on observation of mutual connections of VGDs and relationships with other VGI members, as well as practices in project management, innovation management, inter-organizational cooperation and strategic management.

Phase 2 consisted of member checks in order to validate the accuracy of participant's subjectivity representation. This stage aimed to confront initial findings, eliminate inaccuracies, and identify missing evidence for the considered features, types, actors and their roles in the gaming innovation ecosystem from business practice. We collected data through 17 semi-structured, direct interviews with video game developers, between May 2016 and January 2017 (Appendix 2). We used open questions referring to identified co-creation relationships with different actors inside VGI, outside VGI and within gaming communities; key partners considered in business models. Due to important market differentiation, the interviewees represented different types of video game developers: PC, console, mobile game developers, as well as those operating using premium and fermium (face-to-face) monetization models (Klimas 2017). One firm, due to its extraordinary significance in terms of its capabilities in the implementation of different 
forms of radical innovations i.e. breakthrough, disruptive and game-changingparticipated twice in interviews, in the exploration and clarification phases.

\subsection{Data coding and analysis}

This study adopts a flexible pattern matching approach (Bouncken et al. 2021). We adhere to the postulates of logical consistency (literature-driven), subjective interpretation (emerging), and adequacy (hybrid involving deductive and inductive codes). Hence, we combine theoretical patterns and rigorously identified empirical patterns in a pattern matching exercise. Consistent with our research aim, we "validate or (if possible) extend conceptually a theoretical framework" because "existing theory (...) is incomplete and would benefit from further description" (Hsieh and Shannon 2005: 1281). Therefore this study focuses on expanding the transparency and granularity (Humble 2009) of existing views on GIE actors' roles (Dedehayir et al. 2016; Spelmeyer and Lingens 2018) from the perspective of their engagement in the co-innovation process (Fig. 1). At a more general level, we strive for a "balance between rigid standardization and complete anarchy" (Bouncken et al. 2021: 252) by deploying a pattern matching framework, which operates as an interaction between the deductive and inductive approaches.

Initial coding is theory-driven (i.e., the contexts of new product development, innovation ecosystems and co-innovations in a given industry context). We then use directed content analysis (Fereday and Muir-Cochrane, 2006) as an analytical technique (Hsieh and Shannon 2005) to finally define the list of codes. To code and analyse our data, we followed the conventional process in qualitative research consisting of data reduction, data display and data verification (Miles and Huberman 1994). To address our research questions, we have structured the codes into three categories: actor, role, and co-innovation process.

Regarding the actors, we started with a comprehensive list derived from the literature. Regarding the roles played by actors, we used the four categories identified in prior literature and matched them with the roles reported by our interviewees. Regarding the co-innovation processes, we departed from the literature, which structures these into three, four, or five sub-processes, and found in our data that a more fine-grained list is used by our informants. In order to reinforce the trustworthiness of our coding (Miles and Huberman 1994), we first used data triangulation by confronting the primary data sources with the existing secondary data sources. Next, we validated our findings through member checks with our informants in the second wave of interviews. Thirdly, we triangulated the codes and related findings between the two researchers. 


\section{Findings}

An accurate understanding of innovation ecosystems requires the actors, their respective roles and the processes carried out by those actors to be identified (Dedehayir et al. 2016; Galateanu and Avasilcai 2016; Pattinson et al. 2018; Sun et al. 2019). Accordingly, our findings are structured around actors, roles and co-innovation processes as reported and validated by our informants.

\subsection{Who: the actors involved in gaming innovation ecosystems}

The actors of IE are firms and other organizations, customers and their communities interlinked by the interest in increasing the innovativeness of products, industry, region, or sector of the economy (Pilinkiene and Maciulis 2014; Aarikka-Stenroos and Ritala 2017). By actor we mean an individual or collective entity directly involved in the co-innovation process (Carayannis and Campbell 2009; AarikkaStenroos and Ritala 2017), in value co-creation and value capture (de Gomes et al. 2018; Schroth et al. 2018), but also in fertilizing and accelerating innovation processes (Sun et al. 2019). Generally, actors of innovation ecosystems can be stratified by levels of analysis into four categories: networks of organizations, organizations, individuals, and communities.

Firstly, the literature suggests that innovation ecosystems can be seen as a metaorganizations (Russell and Smorodinskaya 2018; Valkokari 2015) consisting of multi- or meta-organizational (Gulati et al. 2012) actors such as networks, clusters, franchising networks, strategic alliances, etc. However, in our data this type of actor was not identified as no contributors represented the multi-organizational form. Our respondents do not indicate this category, which may be attributed either to its usefulness in GIE involvement or to the somehow abstract construct that networks are.

Secondly, different types of organizational actors including firms, public institutions and NGOs were identified within the GIE, such as: firms producing the final products, competitors, suppliers and complementors. Interestingly, producers of substitutes were not indicated as actors in the GIE. Besides firms, public organizations were also listed, including the government (Ministry of Culture and National Heritage), public institutions (Cracow Technology Park), research institutes (National Centre for Research and Development) and universities (Silesia University). Interestingly, regulators were not indicated by our informants as actors in the GIE. However, not-for-profit organizational actors such as industry regulators (SPIDOR, which informally coordinates the regulatory initiatives imposed by the government and triggers bottom-up ones) and NGOs (Polish Indie Games Foundation or Polish Game Association) are identified as actors in the GIE. ${ }^{2}$

\footnotetext{
${ }^{2}$ In the period covered by the research, there were approximately 300 game developers in Poland (Rodzińska-Szary et al., 2016 - no accurate statistics were kept). Currently, as reported by the Ministry of Culture and National Heritage and the Polish Games Association, more than 400 firms developing games are registered in Poland.
} 
Thirdly, innovation ecosystems are pictured as distinctive because they frame the engagement of social actors (Aarikka-Stenroos and Ritala 2017), both individuals (Autio and Thomas 2014) and communities (Valkokari 2015). Indeed, in contrast to other types of ecosystems, innovation ecosystems cover both sides of the market, namely demand (communities of gamers and individuals such as modders or testers) and supply, and thus cover complete value chains (Stadler and Chauvet 2018: 113). Such a broad scope of actors favours drawing benefits from both co-innovation pushed by the market (producer-led innovation) and pulled by customers (userled innovation, customer-led innovation, market-led innovation). Furthermore, it becomes possible to provide a new value proposition based on more complex solutions linking both of the above (Russell and Smorodinskaya 2018).

Relevant individual actors typically are: consumers (players and gamers diversified in terms of interest in getting involved in the process of co-innovation), nonuser clients (not identified in our case), politicians (the director of the Department of State Patronage in the Ministry of Culture and National Heritage), and investors (not directly identified as really engaged in our case). Our data shows that the list of previously identified individuals is incomplete. We found additional types of individuals that contribute to co-innovation processes implemented within the GIE: modders, hackers and testers involved at the co-development stage of the co-innovation process, thus directly influencing the newly created value. Furthermore, we found influencers to be important individual actors (YouTubers, bloggers, game reviewers, etc.) involved in co-delivery and co-dissemination stages of the co-innovation process by video game developers (Sect. 5.3.).

Fourthly, communities manifesting an interest in engagement in the co-innovation process were also identified by our informants. These collective actors are seen either as communities of interest or communities of practice. Even though it is difficult to draw a clear demarcation line between these two, communities of interest seem to be more focused on improving and tailoring the co-innovation process to the needs of the participants being targeted by the newly created value, such as communities of gamers, amateur testers and modders considered to be a significant source of fan-based value or even determining a game's success. In turn, communities of practice focus on the business perspective, on value creation and value appropriation. Our informants identified such collective actors as: communities of developers, indies, professional testers, scriptwriters and 2D and 3D graphic artists. As suggested by Koch and Bierbamer (2016), these two types of communities can be differentiated through the type of work they carry out for the producer of the final products. Communities of practice are therefore seen as communities of specialists directly working for a producer (here for video game developers), while communities of interest are considered to be communities of users exploited informally, thus working indirectly for a producer.

To conclude, the actors that make up innovation ecosystems are diverse. Their different types (Table 1), importance and specific form seems to depend on the cocreated products underlying the value proposition offered and delivered to the market, i.e. the product defining the innovation ecosystem's boundaries (Tsujimoto et al. 2018). 


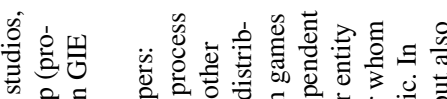

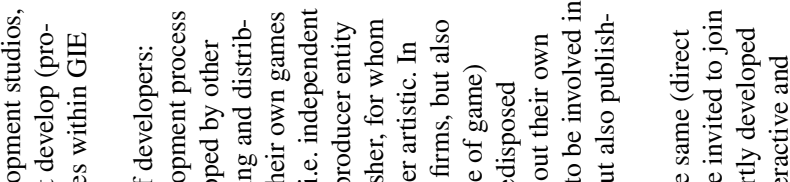

क्ष̃

ष

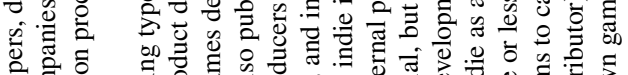

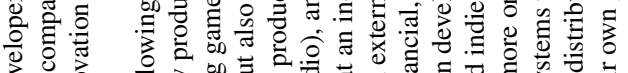

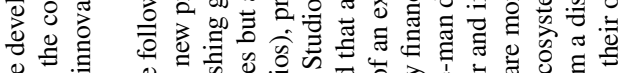

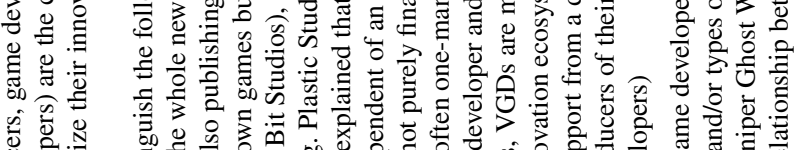

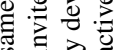

o :

政

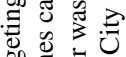

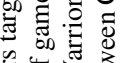

tᄂ

究过

o․ㄹ

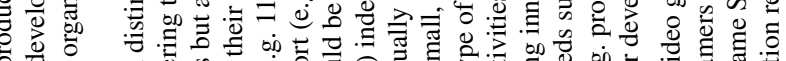

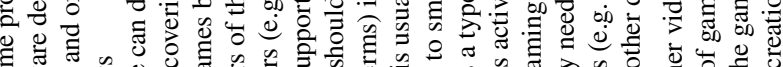

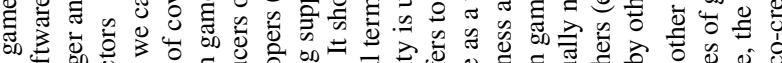

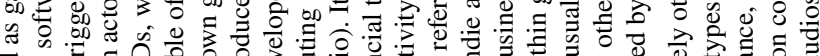

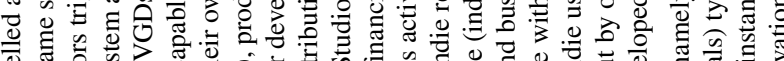

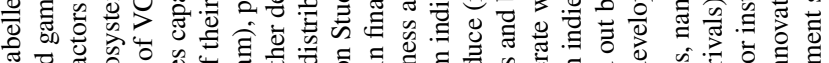

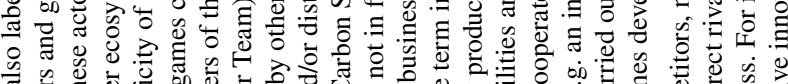

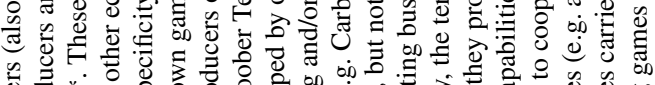

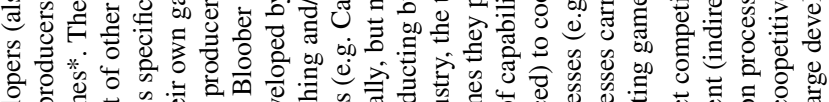

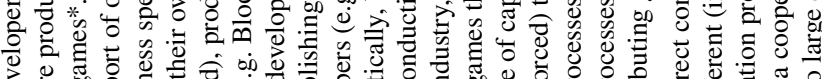

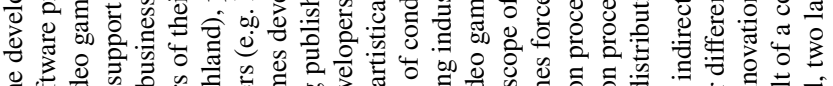

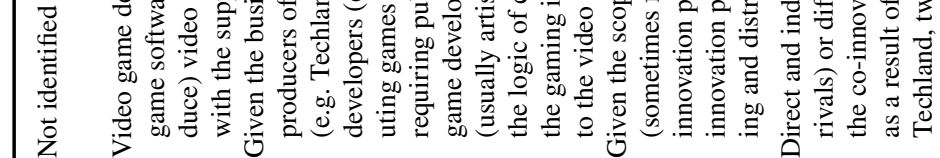

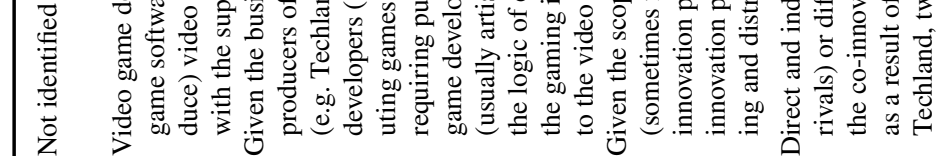

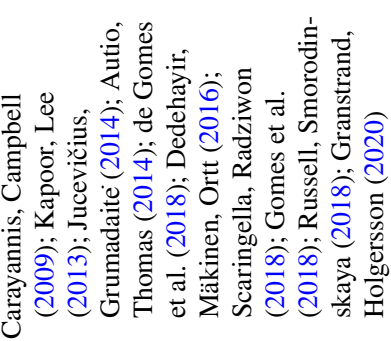

岂

‡ี 


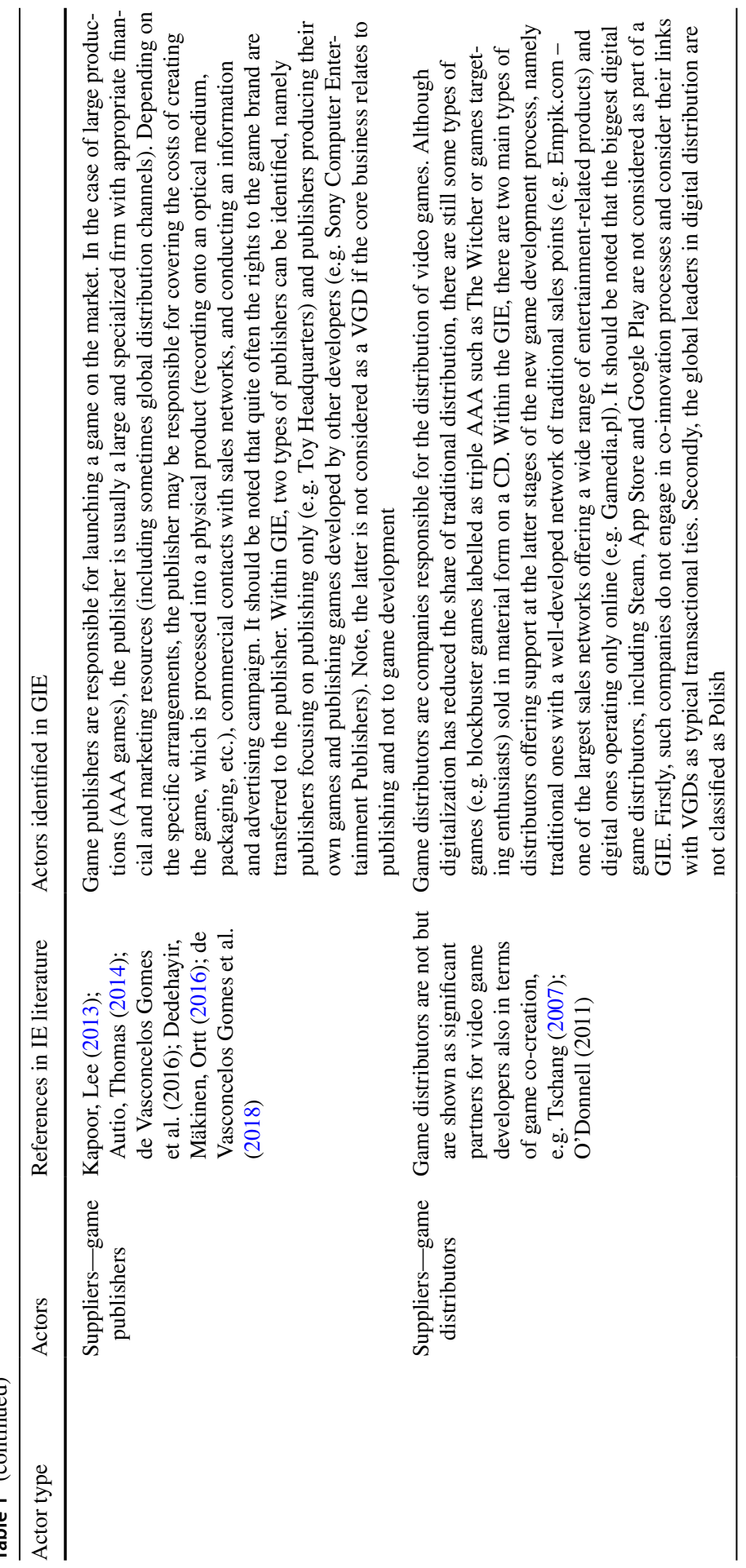




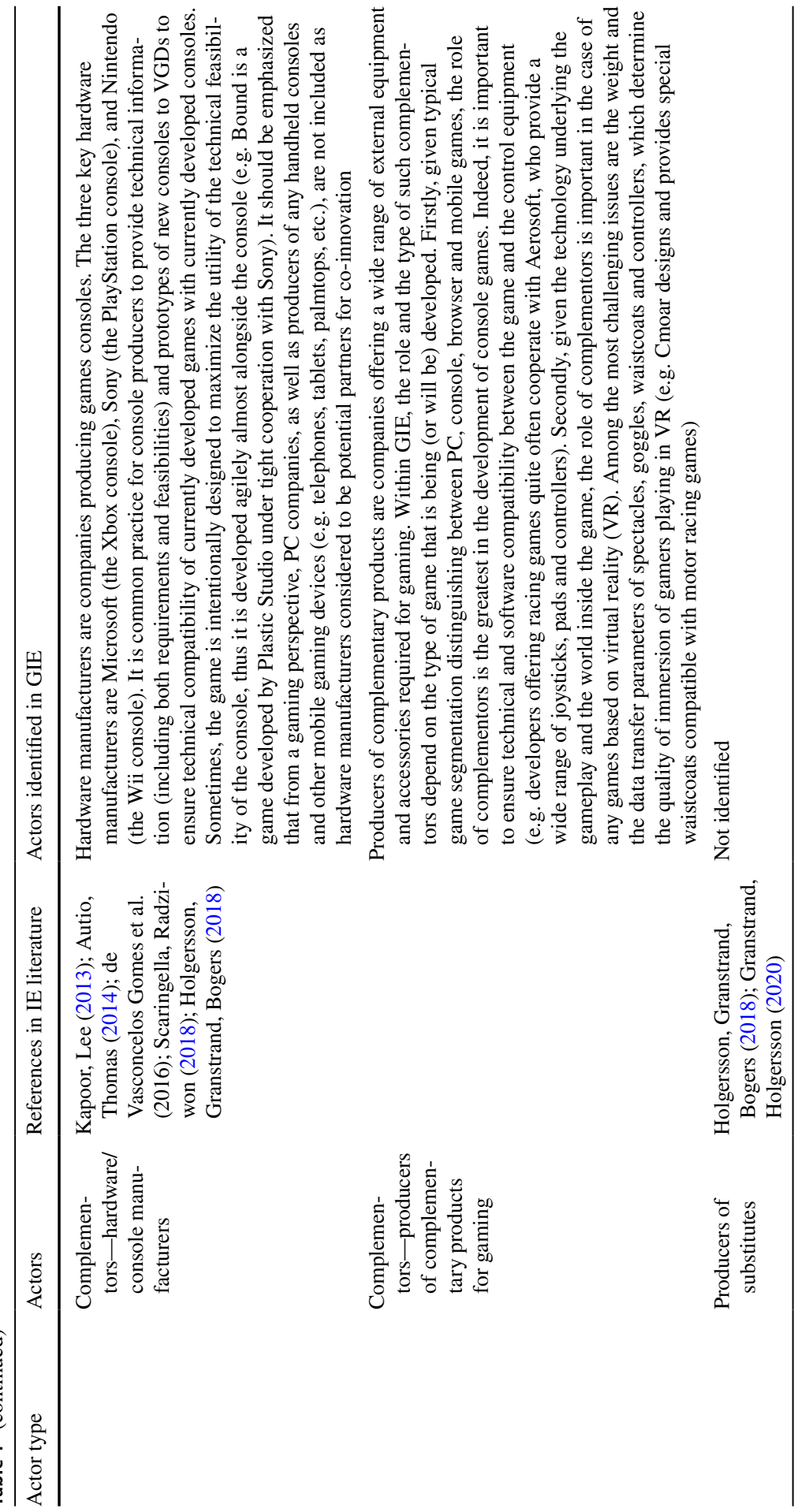




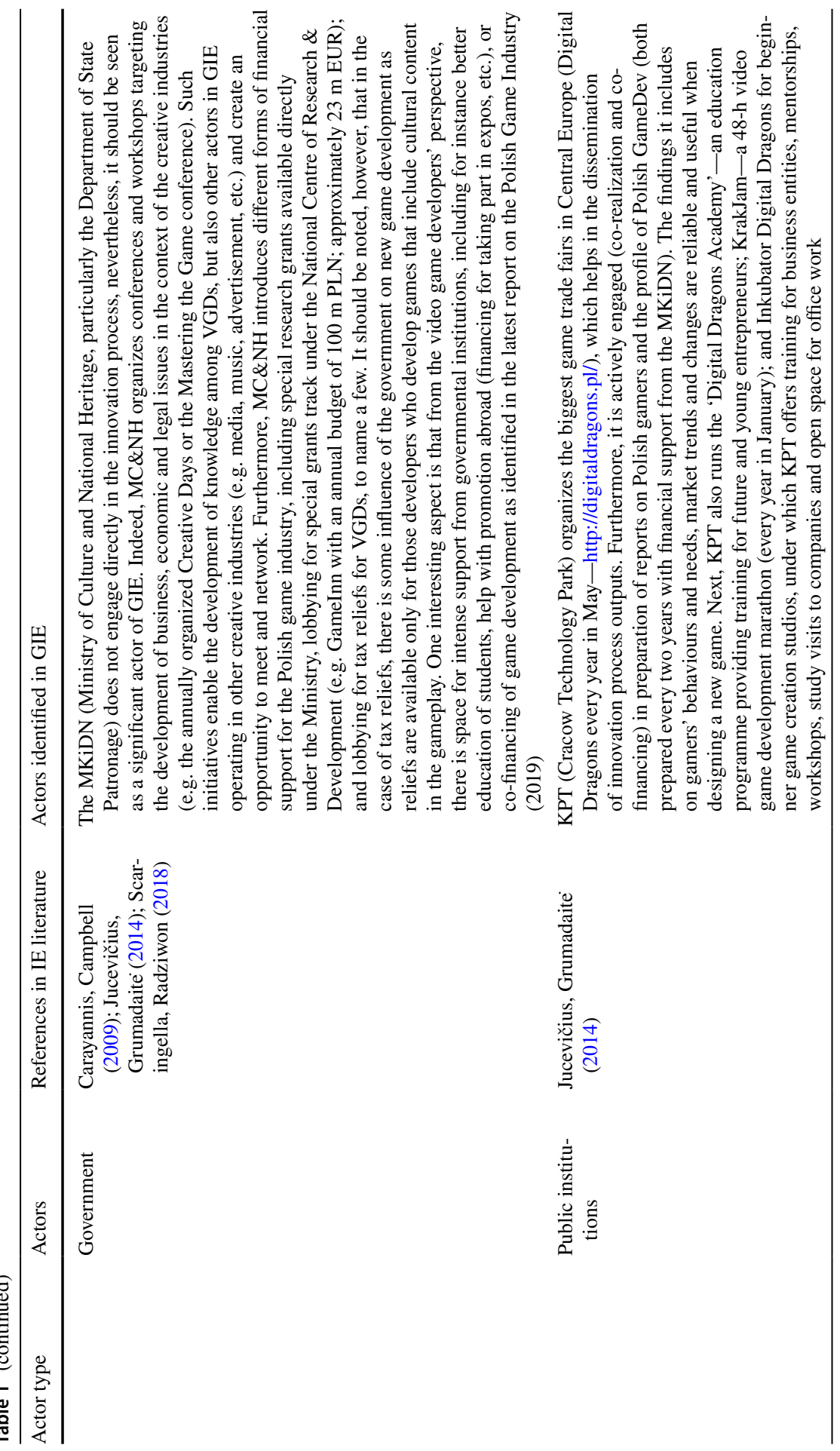




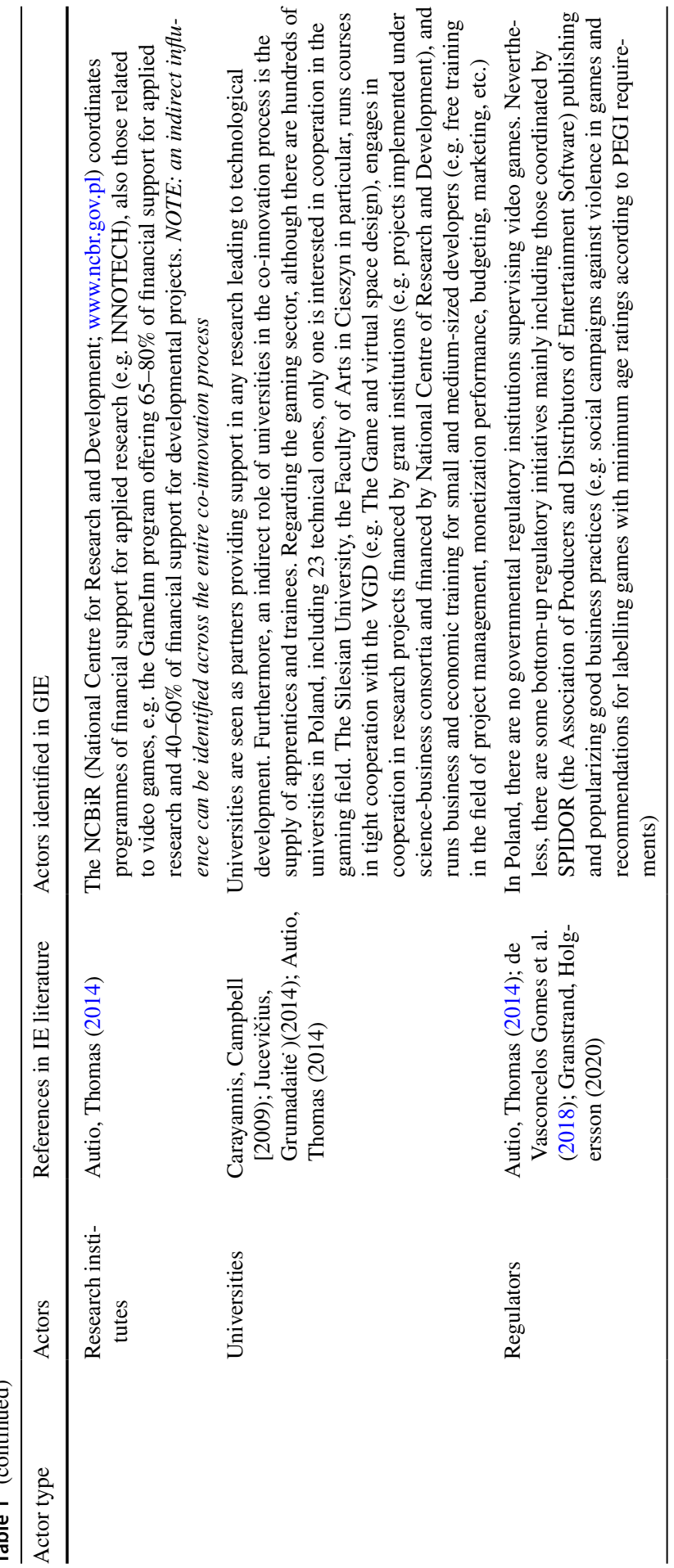




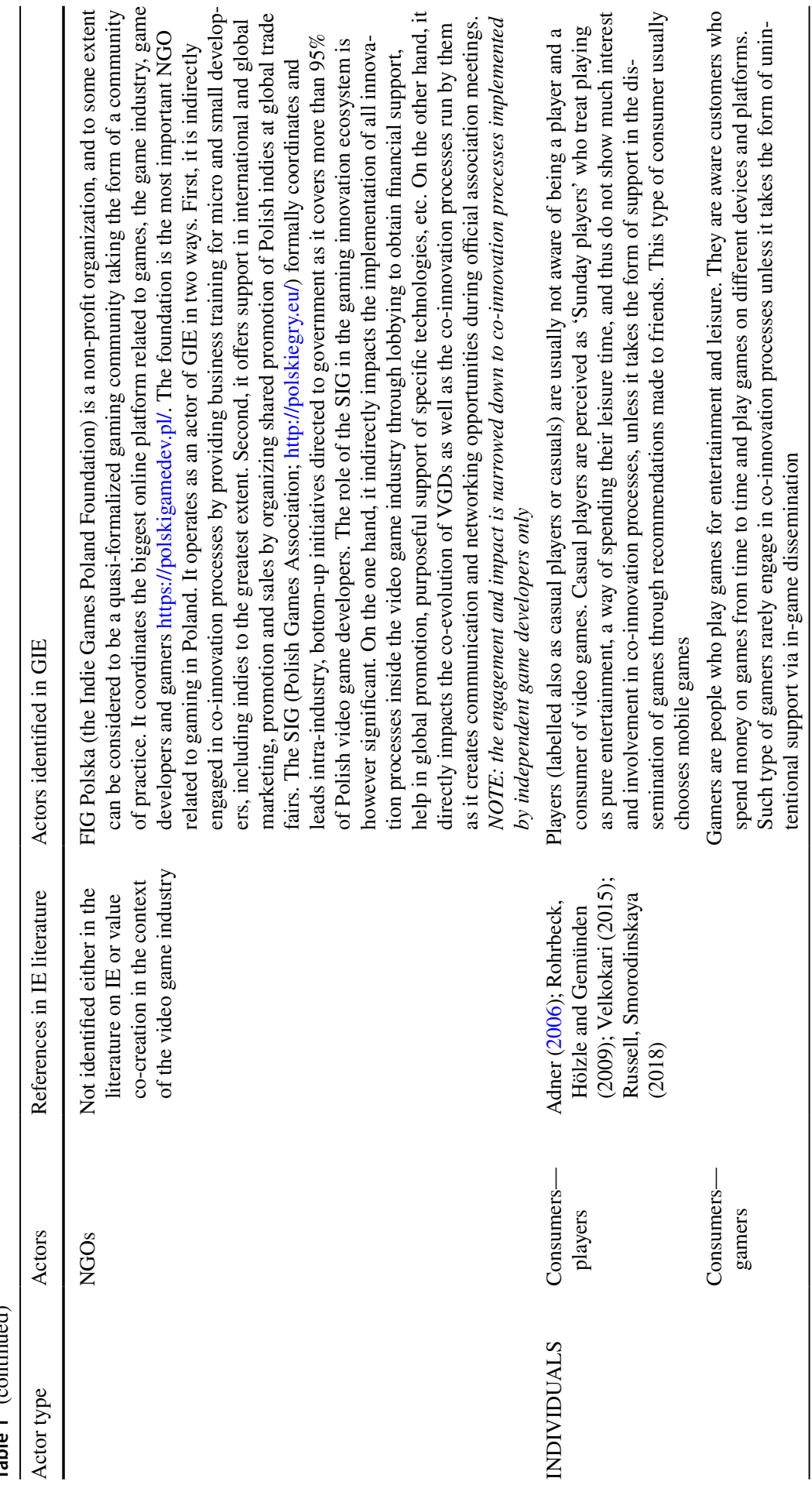




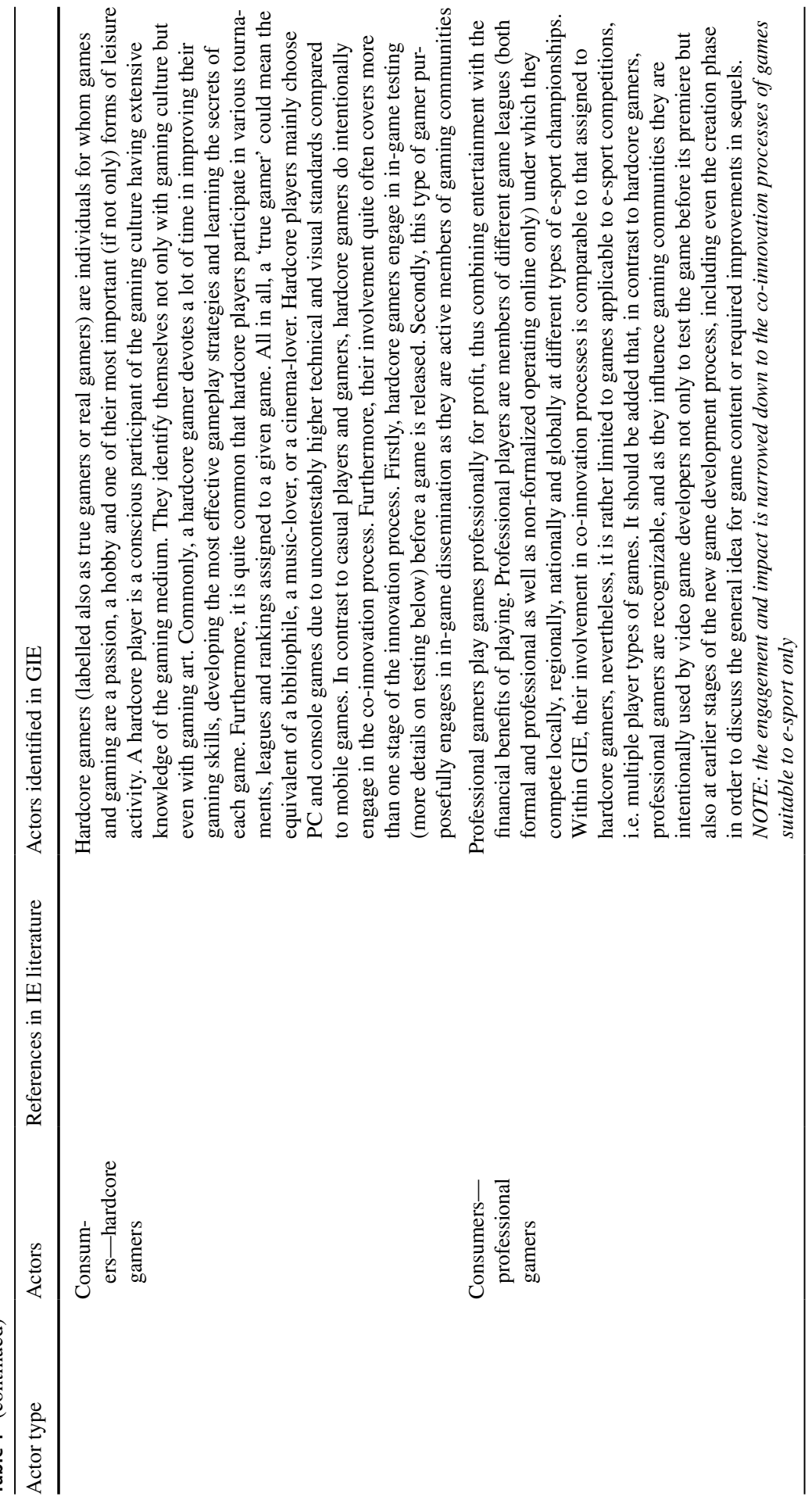




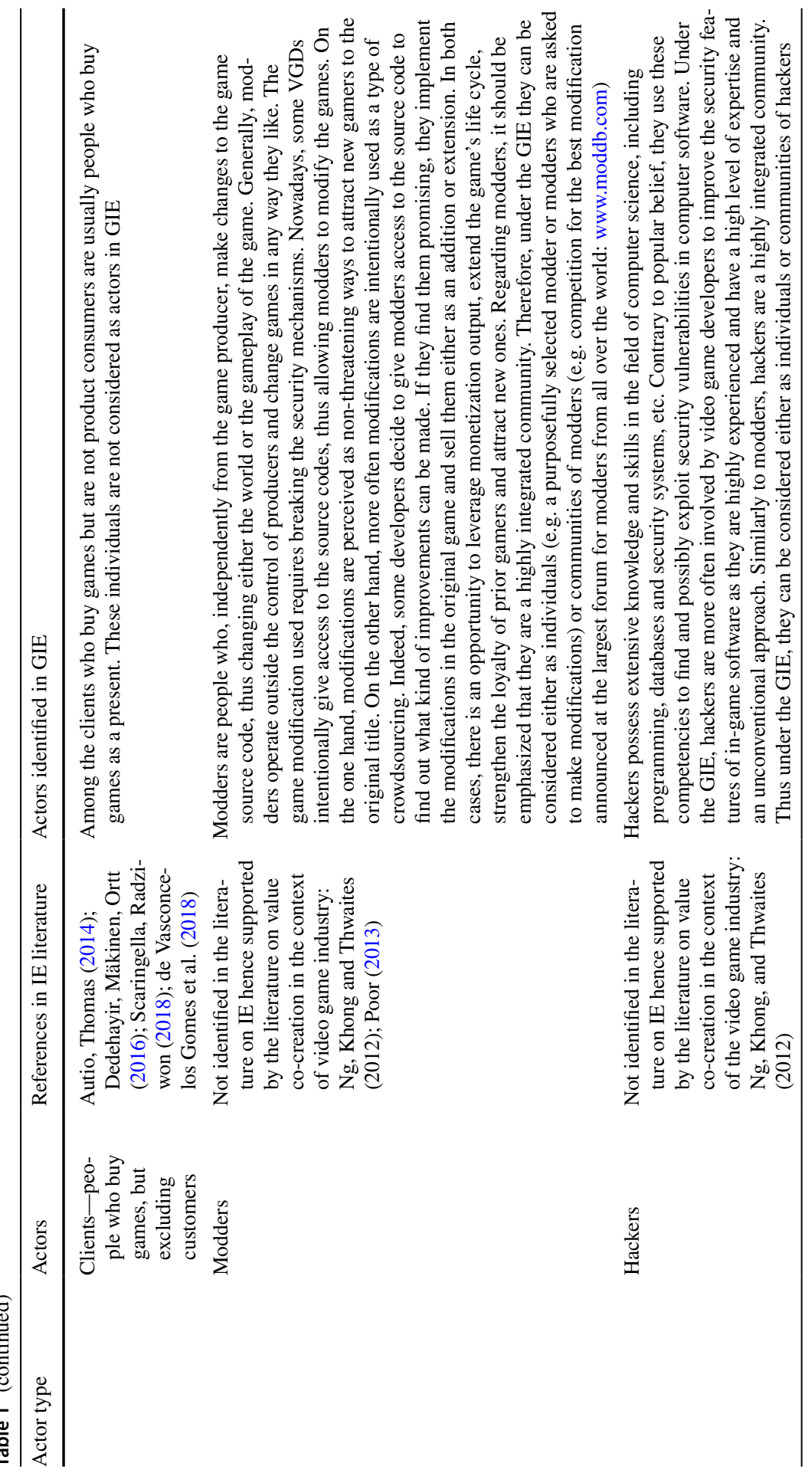




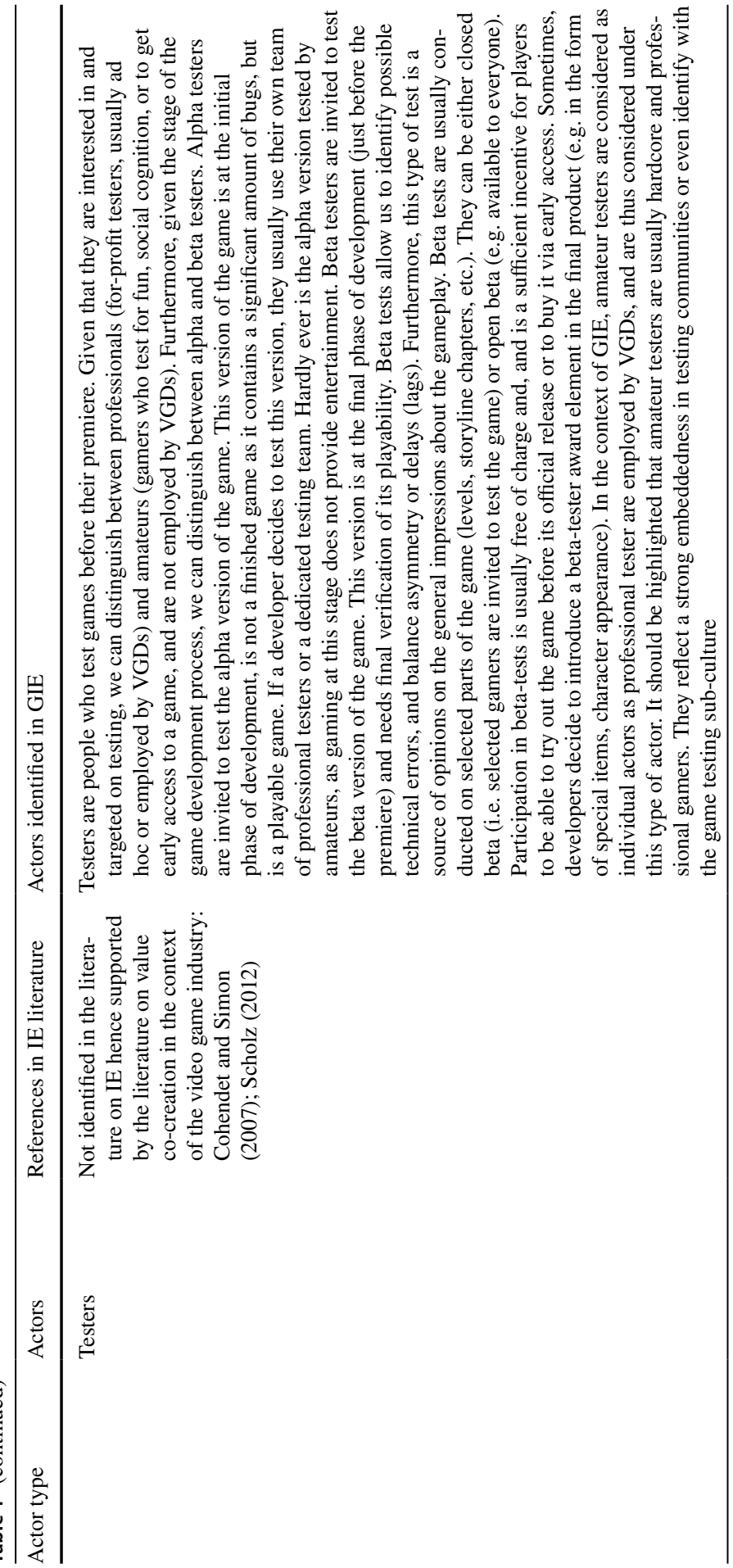




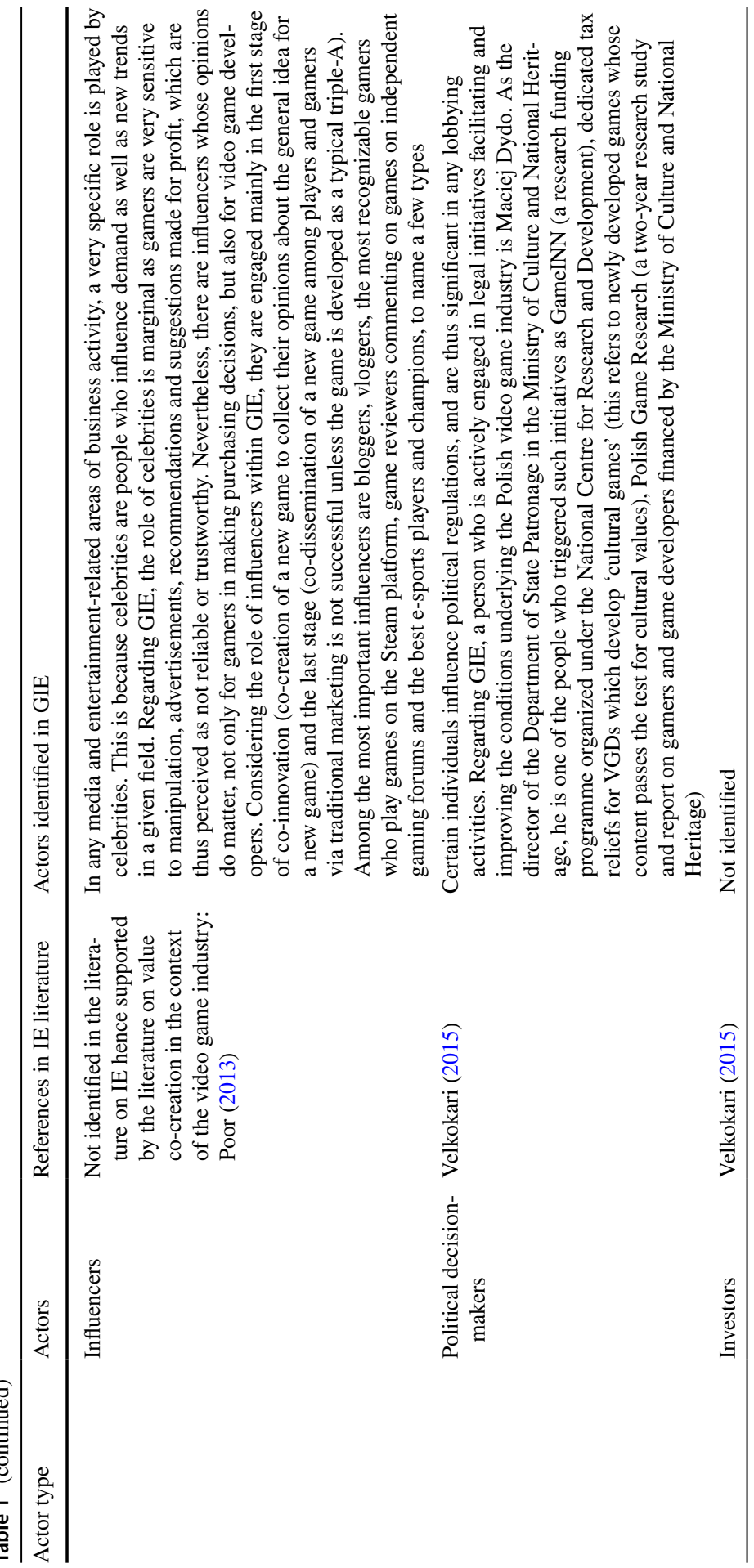




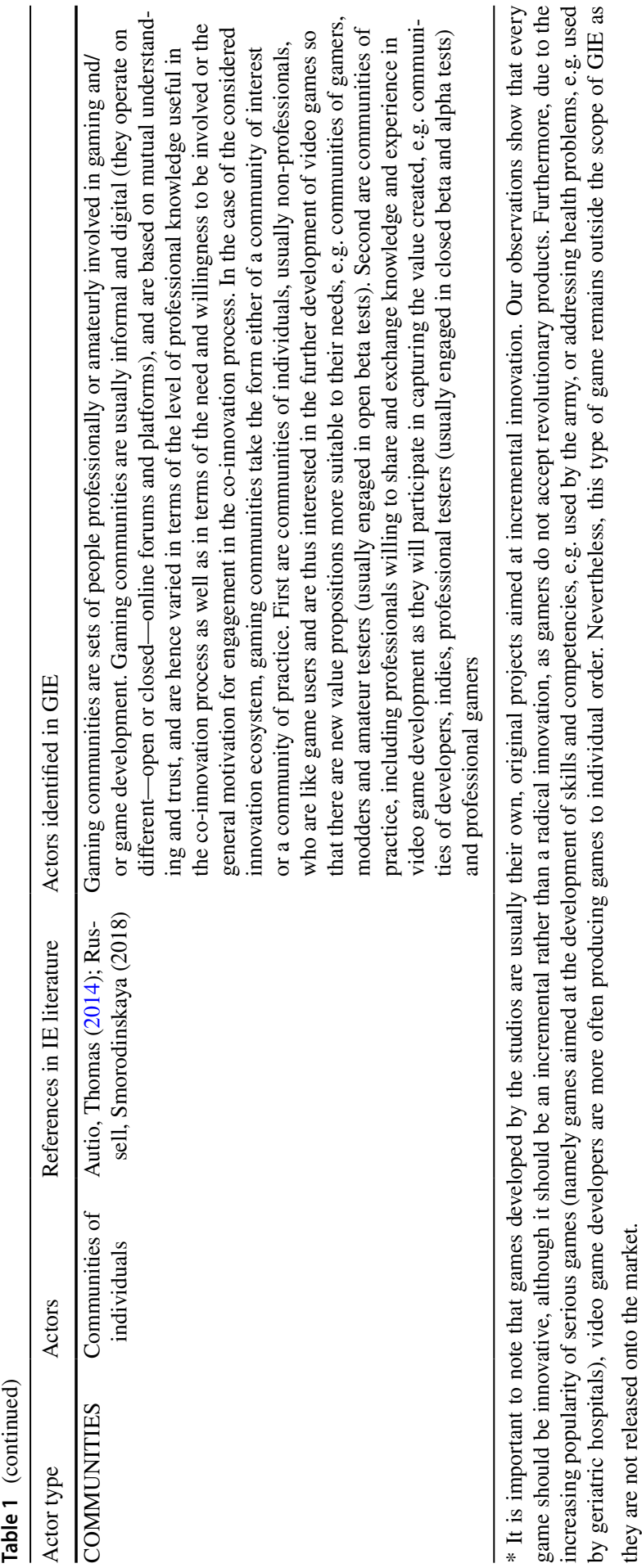




\subsection{What: the roles played in gaming innovation ecosystems}

Our informants indicate that actors within the GIE play various roles in the ecosystem (Dedehayir et al. 2016; Galateanu and Avasilcai 2016; Pattinson et al. 2018; Spelmeyer and Lingens 2018; Sun et al. 2019). We identify four intra-ecosystem roles (Dedehayir et al. 2016): leadership, direct value creation, value support and encouraging entrepreneurship. Nevertheless, not all types of actors play these roles. As shown by Su et al. 2018, the roles should be considered across different areas of IE operations, and thus assigned to specific types of actors. Regarding the GIE, game developers might play all of these roles, however gaming communities or individual gamers and players are not interested in, or capable of taking on the role of leadership or encouraging entrepreneurship (Table 2).

In contrast to firm-centric innovation ecosystems, our GIE is collectively orchestrated by many actors. Hence, the leading role is undertaken collectively by video game developers rather than by one single game development studio. This supports recent findings that the leadership role does not have to be assigned to one player, usually a large focal firm (Spelmeyer and Lingens 2018).

Regarding the direct and supporting contribution to value creation, our informants suggest that although the direct value creation role can be assigned to all actors in the innovation ecosystem, the supportive role seems only to be applicable to those actors not implementing innovation processes i.e. co-innovation processes within the innovation ecosystem. Similarly, the role of encouraging entrepreneurship seems to least suit firms responsible for launching innovation on the market (video game developers).

Our data also shows that independently from taking on a role, some actors are more likely to strongly engage in that particular role than others (Table 3). Thus we map the perception of engagement by GIE actors.

\subsection{When and How: varied involvement in innovation processes}

The differences in actors' involvement can be seen through the lens of their involvement across the stages of the co-innovation processes implemented within the innovation ecosystem boundaries. Our data substantiates prior theoretical suggestions (Dedehayir et al. 2016; Spelmeyer and Lingens 2018) that various actors inside GIEs can be more, less, or not at all involved in the co-innovation processes (Table 4). As one of our interviewees, a developer of AA console games, stated "(...) it depends on what kind of game is being made. Also, it is important at what moment the game is created, these are two things that decide what this co-creation is like and with whom" (VGD_11). This remains in line with prior suggestions linking different actors and the performing of different roles with different impacts on the ecosystem's value proposition (Walrave et al. 2018).

Our informants structure the phases of the co-innovation process according to actors' involvement: co-discovery, co-development, co-deployment, co-delivery and co-dissemination. Co-discovery is focused on concept creation and idea generation, but also on collecting heterogeneous resource support inside the IE, including 


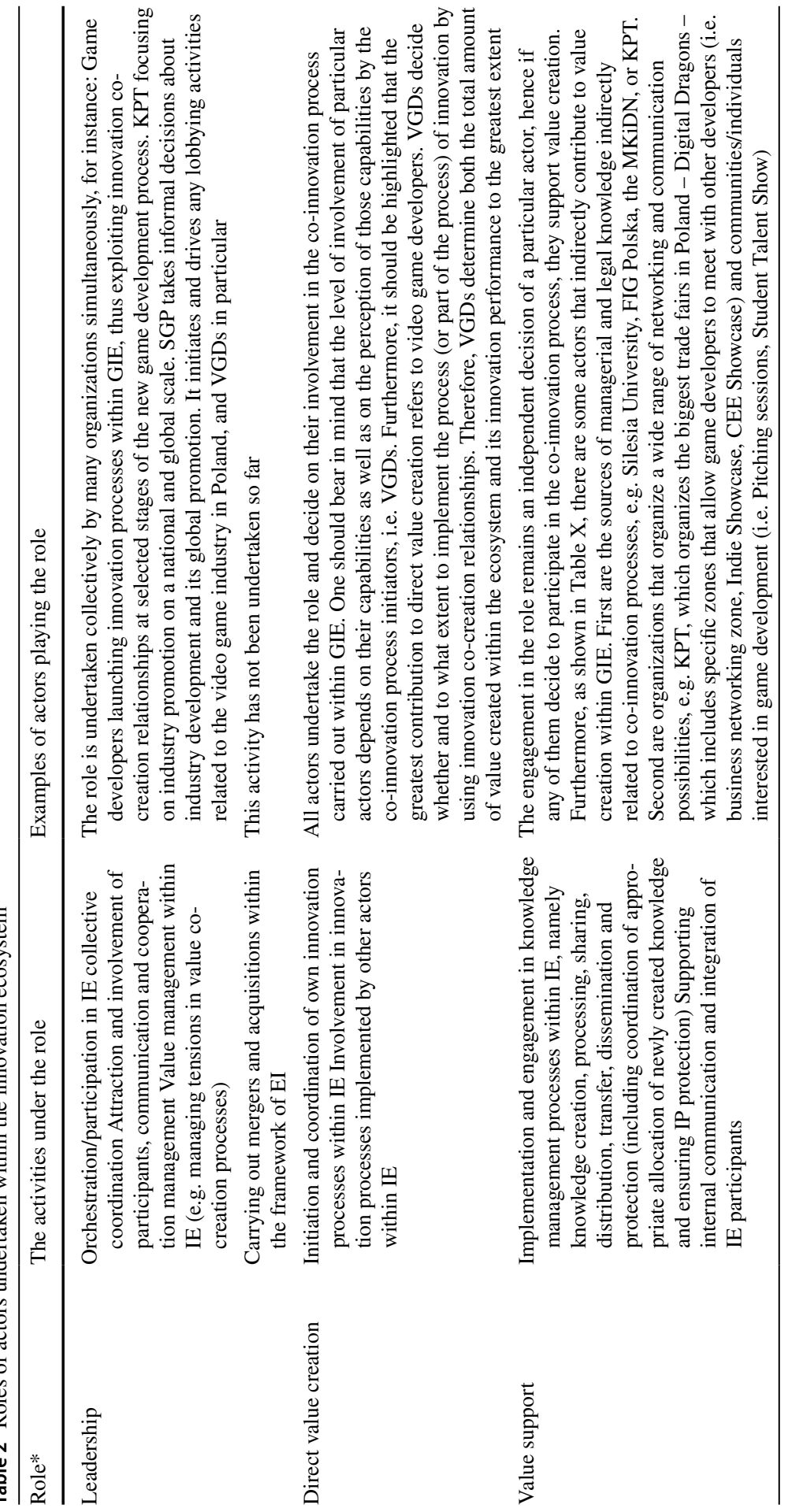




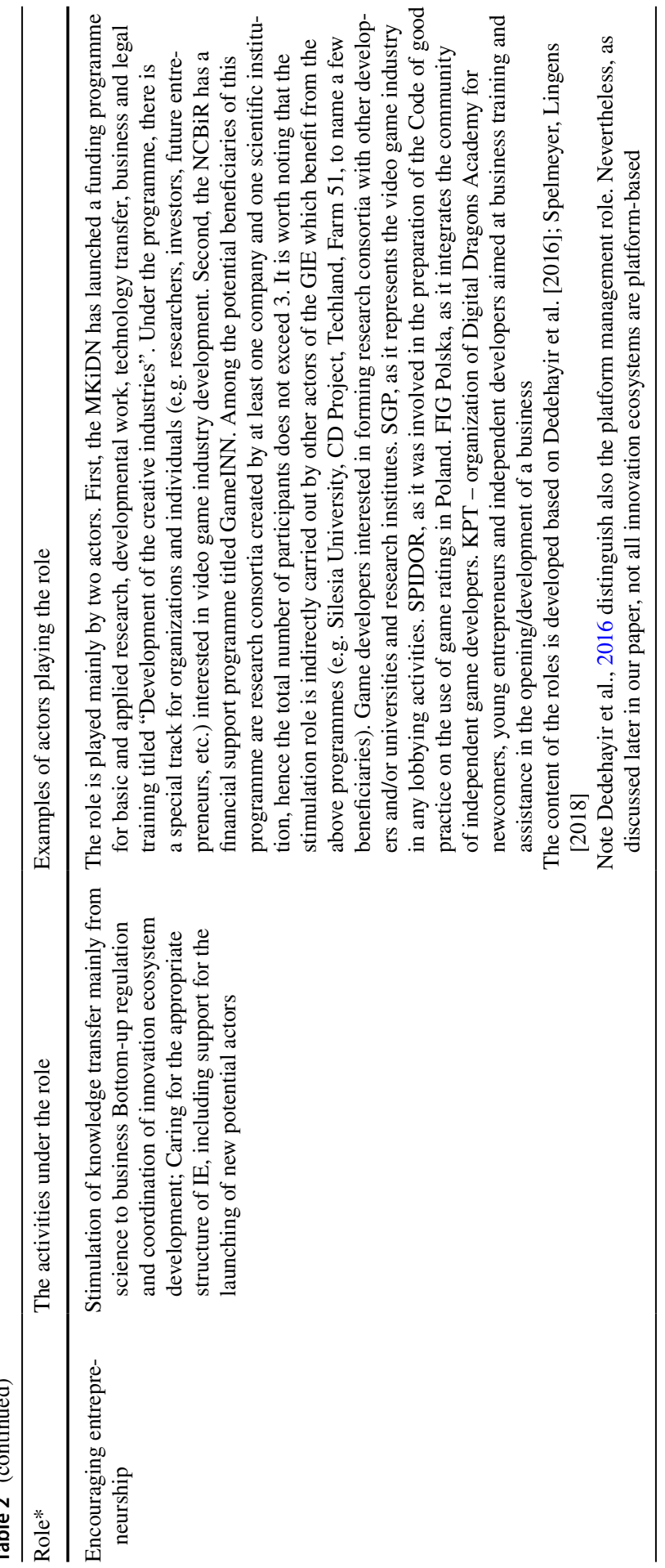




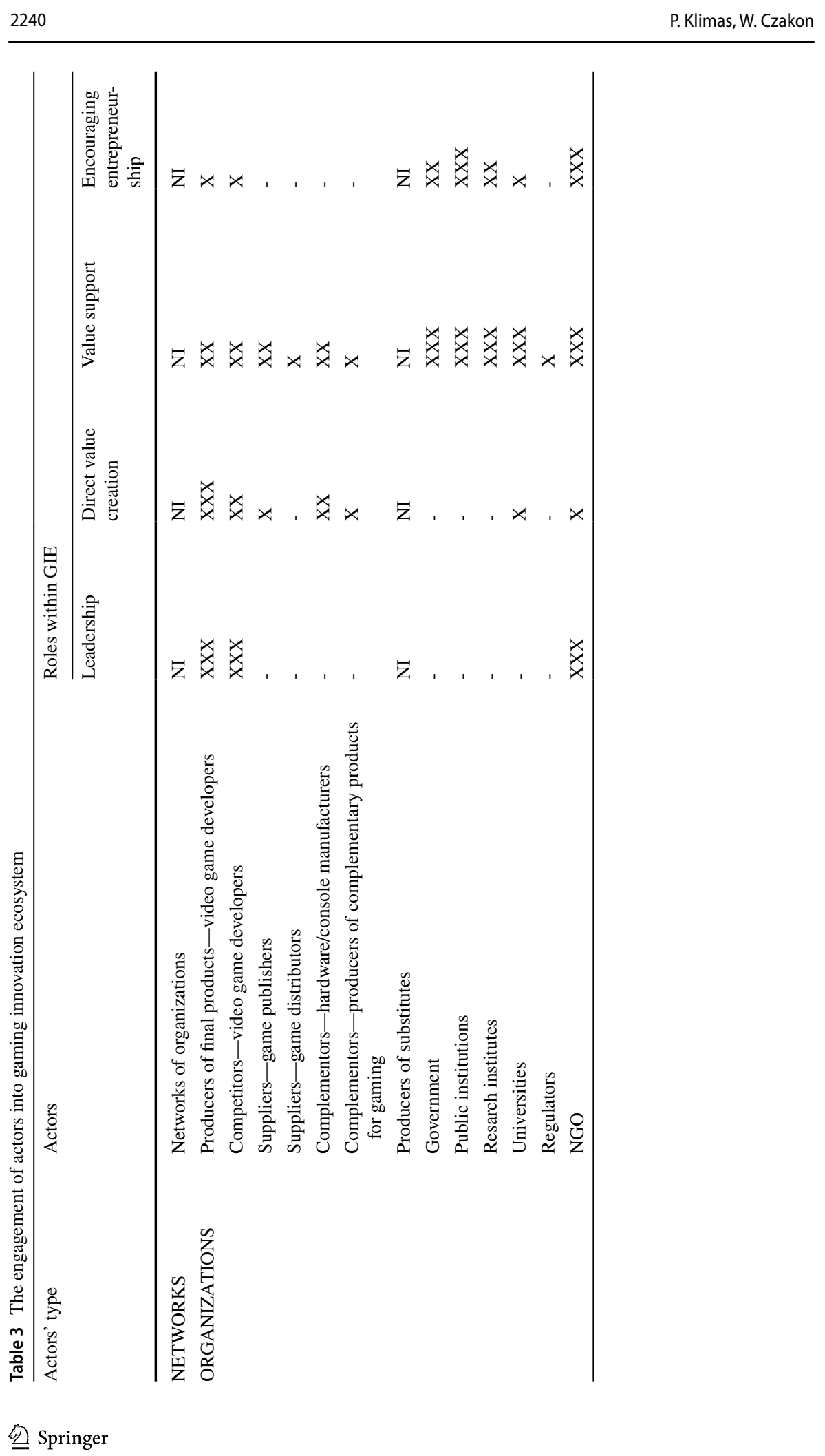




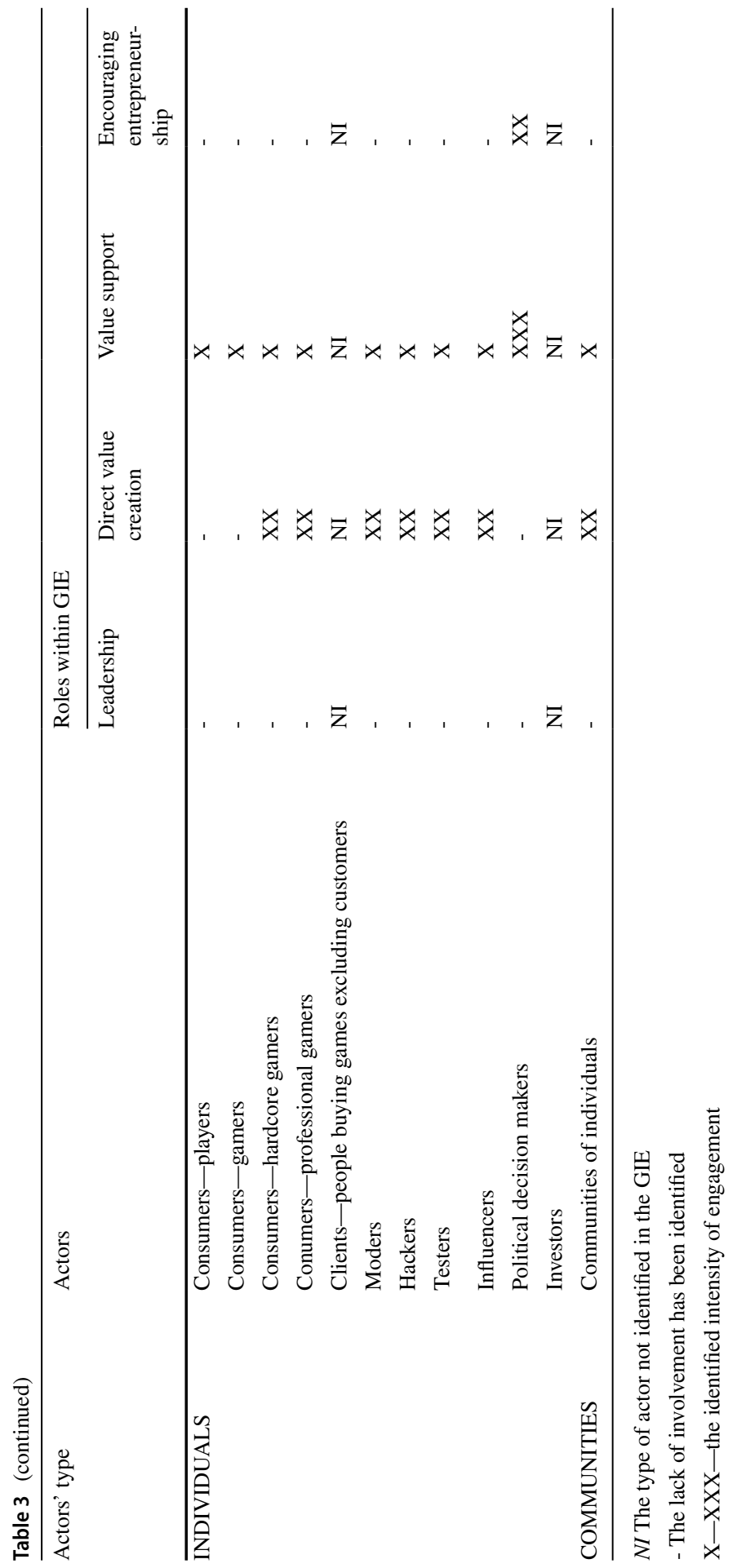




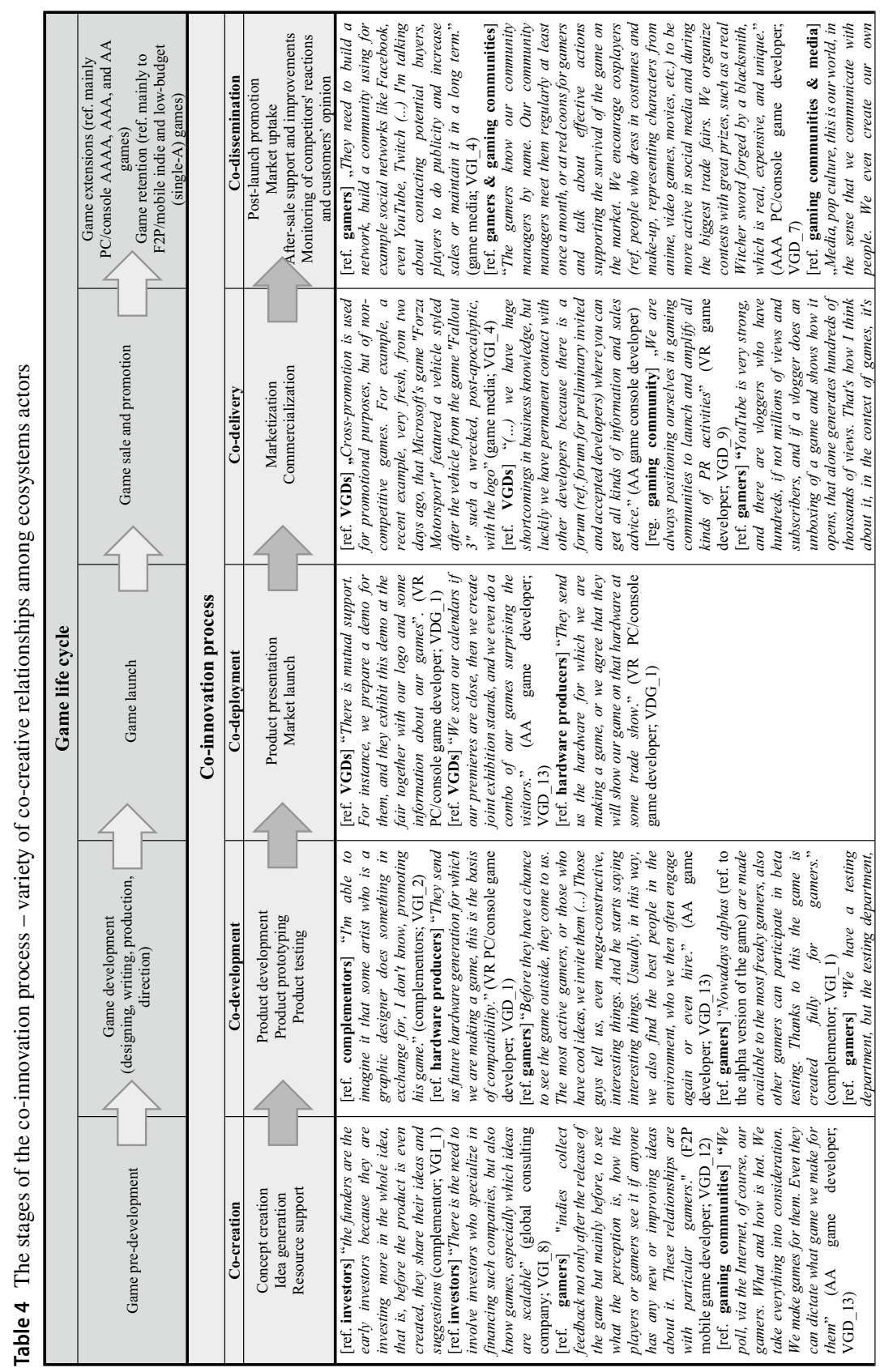




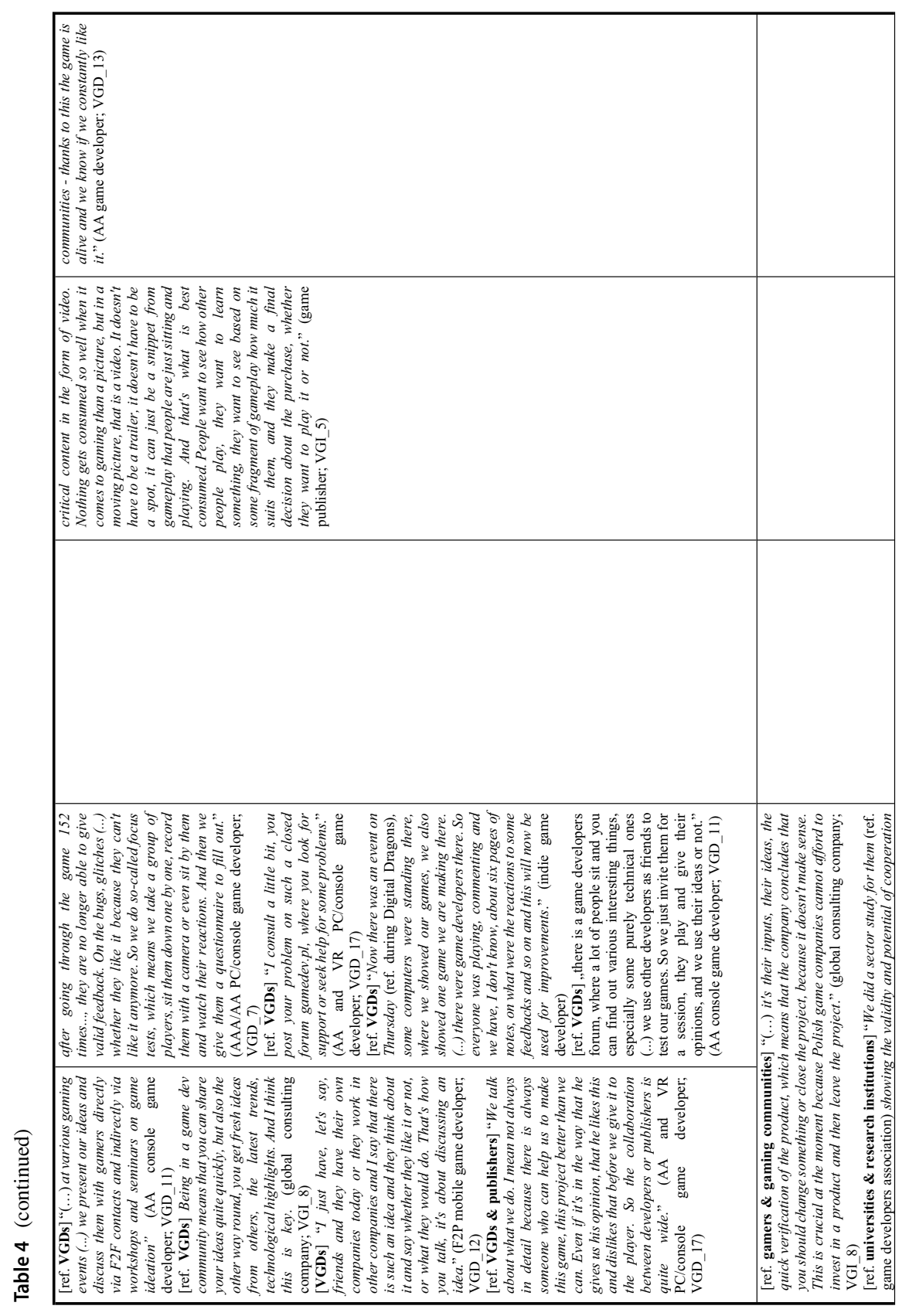




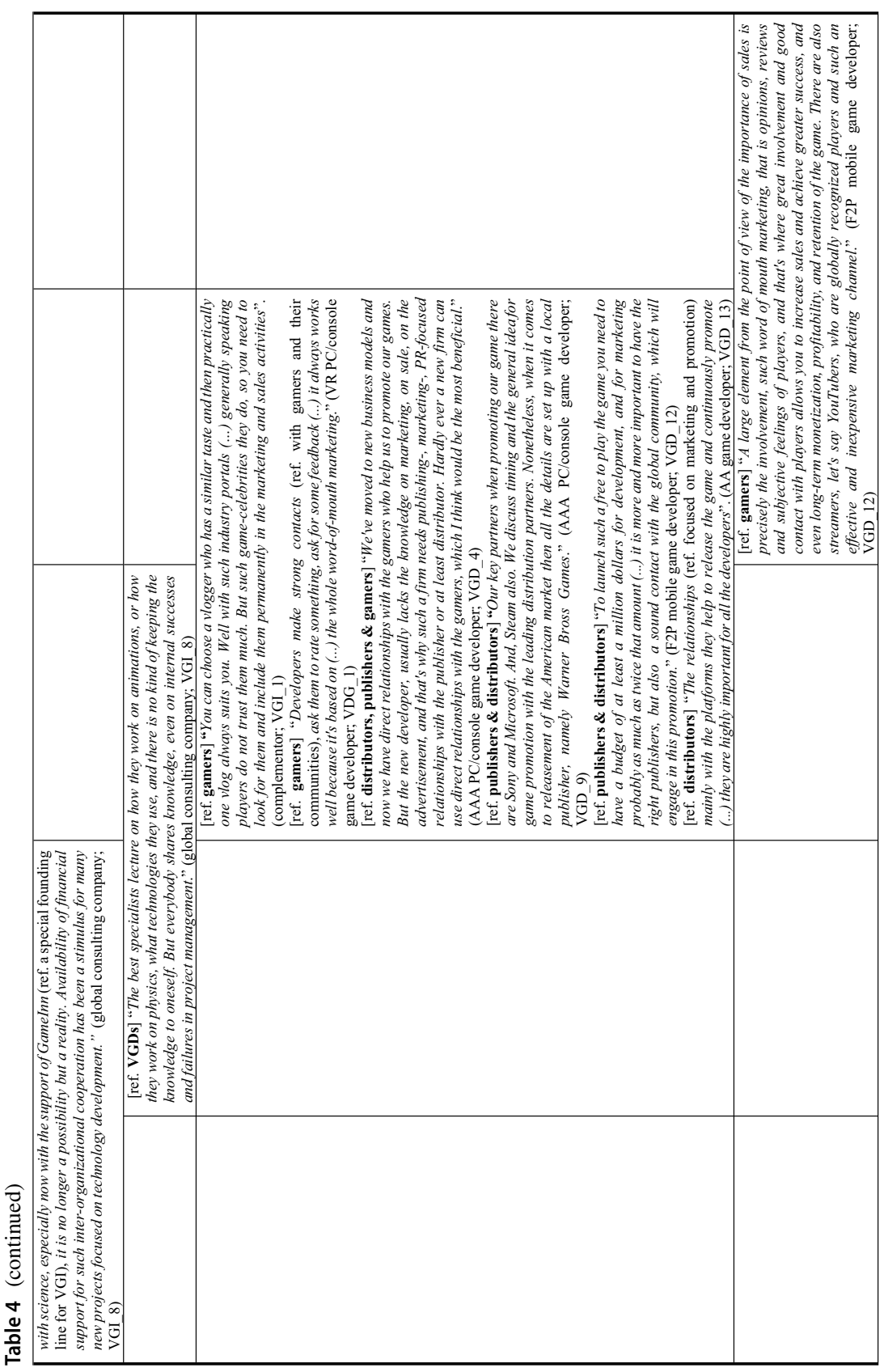



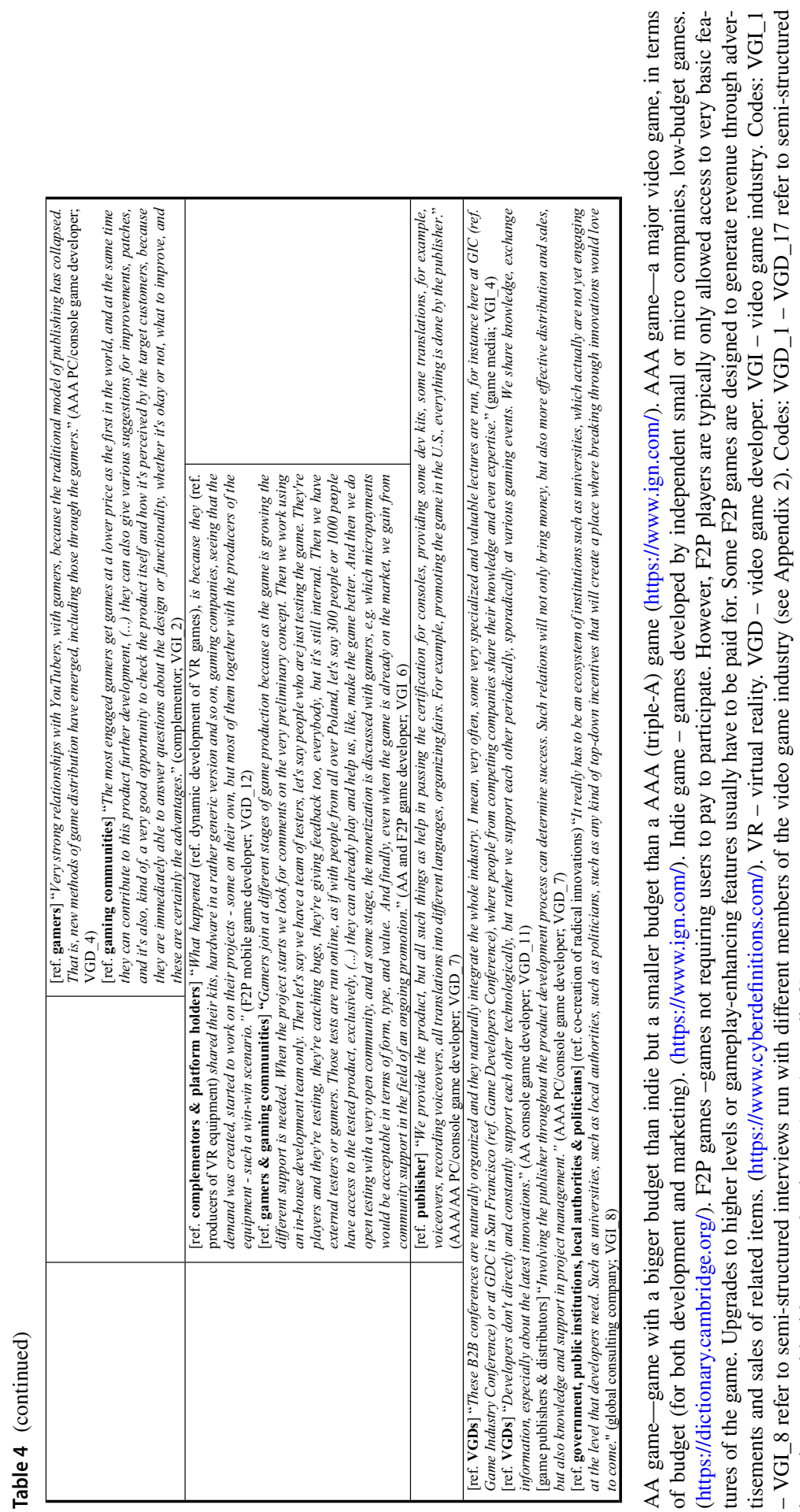

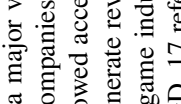

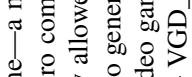

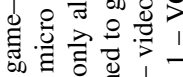

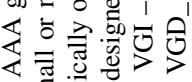

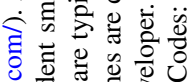

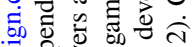

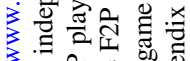

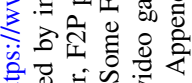

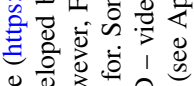

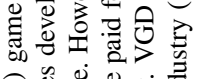

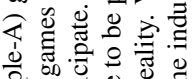

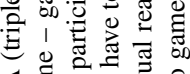

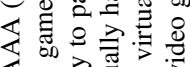

《.:

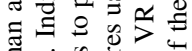

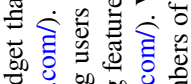

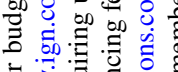

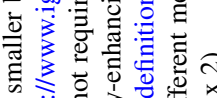

क

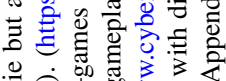

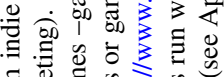

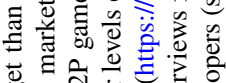

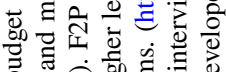

预

.

ส

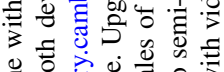

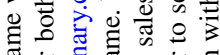

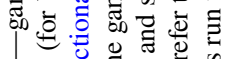

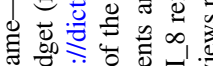

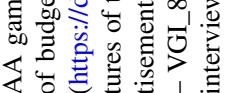


intellectual, cognitive and financial resources. The co-development stage refers to operational work on product development including its prototyping and testing. As reported by our informants, intensive co-creation actions are also aimed at product testing. These tests are carried out at different stages of product development, such as early testing, alpha testing, and beta testing run just before the market launch. The co-deployment stage, which seems to be the shortest sub-phase of the co-innovation process, is aimed at intensive product presentation through promotion assistance, mutual support during trade fairs, etc. given mainly by organizational co-creators and market launch. The co-delivery stage covers mid-term promotional activities aimed at full marketization and game commercialization, mainly carried out with individuals and collectives of individuals (gamers and gaming communities, for instance, in the form of staging game playing with the most popular influencers). The co-dissemination phase refers to involving ecosystem actors in such activities as post-launch promotion, different forms of market uptakes, after-sales support and further improvements of products, and finally monitoring of competitors' reactions and customers' opinions. This stage can be implemented over a very long-term perspective (referring to the extension of $\mathrm{PC} /$ console premium games) or even permanently (referring to the retention of mobile freemium games to maximize product performance).

Summing up, the theoretical path of co-innovation process (Fig. 1) generally matches our data. However, more activities are indicated by our informants than prior literature suggested. For instance, exploitation of resource support in the codiscovery phase, exploiting testing of products in the co-development phase, gaining from inputs into after-sales support and further product improvements, as well as from ongoing customer feedback in the co-dissemination phase (Fig. 1 and Table 4).

Furthermore, depending on the intensity of the involvement of actors across the co-innovation process, some types of actors may be perceived as most desirable and adding contributions at subsequent stages of the process. The engagement of a particular actor type may differ in different co-innovation processes - " they (ref. to gamers or players) can be a co-creator, but on a different scale. As far as the developer allows them, so sometimes, in some areas, it's going to be a kind of consultative influence, but in other situations, it can be a strong impact including an impact on the gameplay or narration style. So, we ask gamers how to balance these weapons, do you like it, is this weapon too strong, is there a sword or a vehicle that's nice, how in the next patch we're going to balance the game, do you see any room for gameplay improvements? It can be extended again with the possibility of creating skins, it can be extended with the possibility of making locations, it can be extended with the possibility of making whole mods, yes, that is a completely different game, the inner game you can say, some advanced scenarios and so on. So, as I said, it's just a matter of what scope gamers will be allowed, what freedom they will be given." (video game developer producing AA and VR games; VGD_17). 


\section{Discussion and conclusions}

The aim of this study was to identify innovation ecosystems from the perspective of those engaged in innovation processes by addressing the variety of actors (who?), the distinct roles (what?), the different stages (when?), and the diverse engagement into co-innovation processes (how?) as perceived by those involved in innovation ecosystems. We flexibly matched (Bouncken et al. 2021) literature-driven categories with the reported perceptions of those involved in innovation processes in order to advance the current understanding of the innovation ecosystem structure and dynamics, as well as the roles and involvement of actors in distinct phases of the coinnovation process.

\subsection{Theory contributions}

Our study offers three noteworthy contributions to innovation ecosystems literature: conceptual, structural and dynamic. We refine Klimas and Czakon's (2021) conceptualization of IE and Granstrand and Holgersson's (2020) three-dimensional framework by developing a more operational definition of innovation ecosystems: a multielement cooperation environment surrounding the framework of innovative activity of its co-evolving actors, organized across the co-innovation process, and resulting in co-creation of new value, delivered to the market in the form of innovation. By introducing co-evolution and co-innovation, we shed light on the interdependencies relevant in ecosystems, and emphasize the variety of roles and interactions that unfold with time.

Secondly, we advance the structural perspective on innovation ecosystems by capturing the respective roles various actors play in innovation co-creation, as perceived by their participants. Prior literature listed actors, roles and processes from the perspective of an external, objective observer grounded in the positivist stance in management research. By adopting a social-constructivist stance, we complement, refine and extend prior claims with the perceptions of those involved in innovation ecosystems. As a result, we develop a two-dimensional view of the innovation ecosystem structure, singling out its actors and innovation co-creation relationships. On the one hand, we confirm and expand the structural view of IE in terms of the engaged actors (e.g. Adner 2017; Granstrand and Holgersson 2020). We identify 12 types of collective actors, 9 types of individual actors, and 1 community of individuals. Our study substantiates that individual customers and their communities are important value co-creators (Prahalad 2004), especially for co-innovation. Interestingly, some actors indicated in the literature, as well as some network organizations, were not identified by our informants, while actors not identified in the literature appeared in our study (e.g. regulators and NGOs). We substantiate respective actors' roles in practice (Dedehayir et al. 2016; Spelmeyer and Lingens 2018). In particular, we found four distinct roles that actors may play in co-creation processes, that is: direct value creation, supporting value creation, encouraging entrepreneurship and leadership. Our data helps to map various actors' engagement in the four identified roles. As in the case of entrepreneurial ecosystems (Bacon and Williams 2021), our 
findings show individuals and communities of individuals with outstanding commitment to be critically important in terms of the intense implementation of an intra-ecosystem.

Thirdly, we also advance the dynamic perspective on innovation ecosystems (Beliaeva et al. 2020; Bouncken et al. 2020; Bouncken and Kraus 2021) by identifying the various degrees of engagement that actors take during the co-innovation process. Based on the GIE participants' perceptions, we structure the co-innovation process (Lee et al. 2012) into five stages: co-discovery, co-development, co-deployment, co-delivery and co-dissemination. We find that actors perceive others and engage in these processes to various degrees over time. Therefore, the roles of actors are not perceived as stable, and depend on the category to which an actor can be assigned. Instead, GIE actors have a broad understanding of co-innovation processes and their potential roles, and that they strategize within these frames and purposefully position themselves in the innovation ecosystem. Such a broad perspective suggests that GIE actors may act as prosumers actively engaged at different stages of coprosumption (Bouncken and Tiberius, 2021). Furthermore, we find support for prior theoretical claims showing differences in the roles performed by particular actors (Dedehayir et al. 2016), but also uncover evidence that there is not an equal distribution of challenges across innovation ecosystem actors (Autio and Thomas 2014; Adner and Kapoor 2010). In line with Dedehayir et al. (2016), the highest engagement in co-innovation processes can be assigned to the companies responsible for putting the co-created value onto the market (video game developers-Table 4). Moreover, our findings show that co-innovation processes, just like innovation processes, require cross-functional cooperation (Ernst et al. 2010; Song et al. 1998), as particular actors engage in different or the same stages while undertaking different or the same roles across those stages. Interestingly, the trust-based rules underlying the very high engagement of competitors at every stage of the co-innovation process, show coopetition and the perception of competitors in coopetition as quite similar within ecosystems and networks (Czakon and Czernek-Marszałek 2021).

\subsection{Practical, regional and social implications}

Our study aims to understand IEs as perceived by their participants. The methodological implications of this stance do not allow for normative statements, as perceptions may vary across empirical settings. Additionally, we focused on identifying what GIE participants actually perceive, not what they should perceive. Therefore we refrain from setting forth normative implications for practice.

However, by finding that roles and degrees of involvement vary over time, we tap into a very important strategic decision that GIE participating actors take. Depending on the role and their engagement, their goals and value capture is likely to differ. Therefore, we encourage GIE actors to develop a broad understanding of the co-innovation process, to map possible positions they may be willing to take, and to purposefully strategize around this map. This may help in sensing opportunities and in effectively exploiting those opportunities. 
Additionally, our method follows the social constructivist approach to the study of organizations. Its distinctive feature is that social structures and processes are enacted by the actors involved. Therefore, such constructs as social norms, identities and legitimate interaction processes come into focus. Innovation ecosystems are not just systems of interaction between innovation processes, but are embedded in social reality. This opens ways for the scrutiny of IE as socially embedded, and helps in fostering the creation and functioning of IE through social action.

Finally, our study reveals the multi-actor facet of IE, and differentiates this facet in terms of the roles and engagement in co-innovation processes. At the meso or macro levels, these findings can be used by local authorities or policy makers to screen, select and work with either the most influential actors, or those undertaking specific actions to expand innovativeness in a given region. The ecosystem concept assumes that the co-creation outputs of ecosystems are beneficial not only within their boundaries. We suggest that the engagement, roles and actions carried out by a wide range of IE actors can generate more general ecosystem effects by fostering regional entrepreneurship (Bacon and Williams 2021; Scott et al. 2021) or digitalization of a particular region or country (Beliaeva et al. 2019).

\subsection{Limitations and further research}

The limitations of our study stem from the methodological choices. Our exploratory and qualitative approach provides limited options for drawing general conclusions, but allows us to make moderate generalizations (Payne and Williams 2005) relevant in social sciences (Finfgeld-Connett 2010). The conceptual framework underlying our exemplification was based on a synthesis of prior systematic literature reviews. Although such an approach is suitable in a rapidly growing field of interest (Czakon et al. 2019), the results of such reviews, as any findings from a review of the literature, are not free from subjectivity (Hagen-Zanker and Mallett 2013; Kraus et al. 2020). In other words, our study's conceptual rigor is indirectly influenced by the emerging stage of innovation ecosystems literature.

Secondly, by taking an in-depth qualitative approach, we were able to map its relevant components as seen by those involved. We relied on individual perceptions, which revealed stability over time and across various respondents. However, we did not explicitly focus on collective understanding, social identity and norms. This opens avenues for further qualitative scrutiny at the collective level of analysis. Additionally, further scrutiny from a more objectivist stance, could be useful in complementing the subjectivity of those involved in IEs.

Qualitative studies are prone to subjectivity biases by the informants and the researchers. In order to address this we have deployed multiple triangulation types, and proceeded with member-checks to validate the accuracy of our findings with our informants to strengthen the rigor and trustworthiness of our findings. We also recognize that perceptions of those involved in GIE may not be stable over time. To address this concern we have run a longitudinal data collection process on a period of 3 years. Nevertheless, we encourage further research across different contexts, 
periods of time, and types of innovation ecosystems in order to gather additional insights before proceeding with large sample studies.

Another limitation of our study stems from the industry focus. While the global nature of the gaming industry (Rodzińska-Szary et al. 2016; Niemand et al. 2021) encourages generalizations, they are bound to the context of gaming industries only. We encourage further scrutiny across other industries as well as dig deeper into recognition if there are any other types of actors relevant in different national context (e.g. probably software complementors including firms providing game engines can be recognized as important co-innovators while in Poland they have not been identified at all).

We also recognize that value co-creation, including the co-creation based on innovating experience (Prahalad and Ramaswamy 2004) that is so important in innovation ecosystems (Klimas and Czakon 2021), is highly contextual. This high level of contextuality can be seen as specific for studies on ecosystems in terms of both the national context (e.g. the Brazilian context - Beliaeva et al. 2019; Italian context - Del Bosco et al. 2020), as well as the industry context, as industry characteristics can also play a role (e.g. position inside the industry, industry dynamics - Bouncken et al, 2020; intensity of competition-Beliaeva et al. 2019; intensity and type of coopetition - Le Roy et al. 2021). Therefore, running a non-contextually limited investigation would be seen as unreasoned at this stage.

Further research could also investigate actors, their roles and their engagement in co-innovation or co-creation processes. Actors' roles (Dedehayir et al. 2016; Spelmeyer and Lingens 2018) and intra-ecosystem dynamics are shown to be relevant and under-researched issues in the entire ecosystem approach (Bouncken and Kraus 2021). This study sheds some light on these issues within innovation ecosystems. Therefore, future replication studies could be run in other ecosystems (Aarikka-Stenroos and Ritala 2017; Scaringella and Radziwon 2018; Tsujimoto et al. 2018; Valkokari 2015), including for instance entrepreneurial ecosystems (Scott et al. 2021), as a recent literature review showed "innovation and dynamics: actors and norms" to be one of the most significant trends in the literature (Fernandes and Ferreira 2021: (1). Furthermore, as the behavioural and cognitive issues have been shown as important for game-playing entrepreneurs (Niemand et al. 2021) they can be also explored in the context of innovation ecosystems. Replication research could also be run in other types of innovation ecosystems (Klimas and Czakon 2022; Pattinson et al. 2018) that are likely to differ in terms of global success, product type and creative nature. Both the choice of empirical setting following the purposeful criterion-intensity and the industry choice call for replicating our study in different contexts. We concur with prior suggestions (Durst and Poutanen 2013) that developing the understanding of innovation ecosystems requires explorative studies focused on delivering empirical data useful in country comparisons as "comparative settings would clarify what factors are likely to remain constant under different conditions" (p.11). We do believe that further replication (Finfgeld-Connett 2010) and explorative (Thomas and Autio 2020) investigations will cumulatively create a coherent and generalizable knowledge base on innovation ecosystems. 


\section{Appendix 1}

\section{Industry-related data sources used when exploring the Polish gaming innovation ecosystem}

\section{Industry reports}

British Council: Mapping the Creative Industries: a Toolkit. "Creative and Cultural Economy” (2001) [access: http://www.creativeconomy.britishcouncil.org] Deloite: 2018 Media and Entertainment Industry Outlook Reaching new heights through personalization and mobility (2018) [access: https://www2. deloitte.com/content/dam/Deloitte/us/Documents/technology-media-telec ommunications/us-tmt-2018-media-and-entertainment-industry-outlook.pdf]

Department for Culture, Media and Sport: Creative Industries Mapping Document (2006) [access: https://www.gov.uk/government/organisations/depar tment-for-culture-media-sport]

European Commission, Directorate-General for Internal Market, Industry, Entrepreneurship, and SMEs: European Competitiveness Report 2010 (2010) [access: http://bookshop.europa.eu/en/european-competitiveness-report-2010pbNBAK10001/].

Forbes: New Reports Forecast Global Video Game Industry Will Reach $\$ 82$ Billion By 2017 [access: https://www.forbes.com/sites/johngaudiosi/2012/07/ 18/new-reports-forecasts-global-video-game-industry-will-reach-82-billionby-2017/\#3c83066d440a]

Interactive Software Federation of Europe: Videogames in Europe: Consumer Study. European Summary Report. (2012) [access: http://www.isfe.eu/sites/ isfe.eu/files/attachments/euro_summary_-_isfe_consumer_study.pdf]

Interactive Software Federation of Europe: Videogames in Europe: Consumer Study. Poland. (2012) [access: http://www.isfe.eu/sites/isfe.eu/files/attac hments/poland_-_isfe_consumer_study.pdf]

NewZoo: Global Games Markert 2016 (2016) [access: http://resources.newzoo.com/global-games-market-report]

NewZoo: Global Games Markert 2017 (2017) [access: https://newzoo.com/ insights/articles/the-global-games-market-will-reach-108-9-billion-in-2017with-mobile-taking-42/]

PwC: Entertainment \& Media Outlook for Europe 2015-2019 (2016) [access http://nck.pl/media/attachments/318169/raport-media-outlook-pwc-2016.pdf] PwC: Global video games market, segmented by forecast rate of growth and scale, 2013-2018 (2014) [access https://www.pwc.com/gx/en/global-enter tainment-media-outlook/assets/2014/pdfs/video-games.pdf]

Rodzińska-Szary, P., Bobrowski, M. \& Socha, M. (2016). Kondycja polskiej branży gier. Raport 2015. [access: http://kreatywna-europa.eu/wp-content/uploa ds/2016/01/Raport-na-temat-kondycji-polskiej-branży-gier-wideo-1-1.pdf] 
Bobrowski, M., Rodzińska-Szary, P., Krampus-Sepielak, A., Śliwiński, M. \& Rudnicki, S. (2018). Kondycja polskiej branży gier. Raport 2017. [access: https:// www.cdprojekt.com/pl/wp-content/uploads-pl/2016/03/kondycja-polskiejbranzy-gier17.pdf]

SuperData Research: De-risking game development in the digital era (2016) [access: www.superdataresearch.com]

SuperData Research: Global Games Report - 2015. Entering the next era of interactive entertainment(2015). [access: www.superdataresearch.com]

SuperData Research: Payment preferences of digital gamers. Global payment methods \& brands. Industry trends \& analyses. SuperData - 2016 [access: www. superdataresearch.com]

United Nations: Creative Industries and Development (2004) [access: http:// www.unctad.org/en/docs/tdxibpd13_en.pdf]

\section{Industry websites}

Websites of the members of video game industry including video game developers (e.g. CD Project, Techland, the Farm 51), video game publishers (e.g. EA Games Polska), video game distributors (e.g. Steam, Twitch, Empic, Amazon), console manufacturers (i.e. Microsoft, Sony), independent game developers (i.e. http://1ndieworld.com/), industry association (i.e. Indie Games Polska: https://www.facebook.com/fundacja.igp/; Polish Games Association: http:// polskiegry.eu/), others (i.e. formal and informal meta-organizations such like www.eurogamer.net, www.alphabetagamer.com, www.kickstarter.com).

Online portals focused on video games, e.g. Mobygames.pl, Gameproducer. net, Gamasutra.pl, Gamewatch.org, Padportal.pl, Gameonly.pl, Gry-online.pl, Gram.pl, Miastogier.pl, Gamelog.pl, Gry.onet.pl, Gameplay,pl.

Online forums for gamers and gaming communities, e.g. http://www.games board.pl, http://www.giermania.fora.pl, http://game4fun.pl.

Blogs and videoblogs run by gaming influencers, e.g. http://www.11-22.pl, http://www.taisho.pl, http://wieotematycznyograch.blox.pl/html, http://mojeg rykomputerowe.blox.pl/html, http://blondynkitezgraja.pl, www.bigfishgames. com/blog.

\section{Appendix 2}

\section{Sources of triangulated primary data used in the study}

\section{Phase 1 of data collection - an initial exploration}

Aim: answering the question if (and how) can we perceive Polish video game developers as operating within the gaming innovation ecosystem. 
Data collection techniques applied.

- 13 structured interviews with video game developers carried out in May 2015 including:

- 4 non-Polish companies;

- 7 interviews with creative workers and 6 with owners/top managers;

- Average time of reviewing: $21 \mathrm{~min}$;

- Codes: STR_1 - STR_13

- 8 semi-structured, direct interviews with different members of the video game industry carried out between October 2015 and March 2016 including:

- 1 big video game development studio, 2 producers of complementary products for gaming, 1 branch of global video game publisher, 1 independent video game developer, 1 online portal about games and game industry, 1 consulting company preparing reports and industry analyses at the national and global scale, 1 newcomer so far operating as a business partner for big developers;

- 8 interviews with top managers and owners;

- Average time of reviewing: $65 \mathrm{~min}$;

- Codes: VGI_1 - VGI_8

- 5 field, non-participatory observations organized during the biggest trade fairs and industry conferences in Poland between May 2015 and November 2016 including:

- Digital Dragons organized by Cracow Technology Park in Cracow - attended twice;

- Game Industry Conference organized together with Game Arena Trade Show in Poznań by Poznań University of Technology and all industry association (formal and informal ones) - attended twice;

- Mastering the Games organized by the Ministry of Culture and National Heritage in Warsaw - attended once.

\section{Phase 2 of data collection - the discussion, verification, and enrichment of initial findings}

Aim: support of initial findings, elimination of conclusions drawn in a wrong way, identification of missing evidence for considered features, types, actors, relationships in gaming innovation ecosystem from business practice.

Data collection techniques applied.

- 17 semi-structured, direct interviews with video game developers carried out between May 2016 and January 2017 including: 
- 3 big / 6 medium / 3 small / 5 micro-firms;

- 9 firms developing premium games / 3 firms developing free-to-play games / 8 operating at both premium and F2P segments;

- 4 companies listed on the Warsaw Stock Exchange and 2 companies listed in NewConnect at Warsaw Stock Exchange;

- 9 companies operating only as video game developer / 3 companies operating as video game developer and publisher / 1 company operating as video game developer and distributor / 4 companies operating as video game developer, distributor, and publisher;

- 17 interviews with top managers and owners;

- Average time of reviewing: 83 min;

- Codes: VGD_1 - VGD_17

Acknowledgements This paper was presented at 14th Academy of Innovation, Entrepreneurship, and Knowledge Conference: Innovation, Management, and Governance for Sustainable Growth (Sorbone; June 2021). We would like to thank the conference Reviewers for all of the remarks and suggestions to our very first version of the paper. We thank also the Editors and Reviewers form Review of Managerial Science for their insightful and constructive comments.

Funding The project was financed from sources of National Science Centre, Poland according to decision UMO-2013/11/D/HS4/04045. The dissemination of findings received funding from the Ministry of Science and Higher Education in Poland under the program "Regional Initiative of Excellence" 2019-2022 contract number 015/RID/2018/19 signed at 12/20/2018 for total funding amount of 10721 040,00 PLN.

Data availability Primary, raw data will be made available on reasoned request. Note that the study was run in Poland, therefore the collected empirical material is in Polish.

\section{Declarations}

Conflicts of interest The authors declare that they have no conflict of interest.

Open Access This article is licensed under a Creative Commons Attribution 4.0 International License, which permits use, sharing, adaptation, distribution and reproduction in any medium or format, as long as you give appropriate credit to the original author(s) and the source, provide a link to the Creative Commons licence, and indicate if changes were made. The images or other third party material in this article are included in the article's Creative Commons licence, unless indicated otherwise in a credit line to the material. If material is not included in the article's Creative Commons licence and your intended use is not permitted by statutory regulation or exceeds the permitted use, you will need to obtain permission directly from the copyright holder. To view a copy of this licence, visit http://creativecommons.org/licen ses/by/4.0/.

\section{References}

Aarikka-Stenroos L, Ritala P (2017) Network management in the era of ecosystems: systematic review and management framework. Ind Mark Manage 67:23-36. https://doi.org/10.1016/j.indmarman. 2017.08.010

Adner R (2006) Match your innovation strategy to your innovation ecosystem. Harv Bus Rev 84(4):98-107

Adner R (2017) Ecosystem as structure : an actionable construct for strategy. J Manag 43(1):39-58. https://doi.org/10.1177/0149206316678451 
Arora A, Belenzon S, Patacconi A (2019) A theory of the US innovation ecosystem : evolution and the social value of diversity. Ind Corp Chang 28(2):289-307. https://doi.org/10.1093/icc/dty067

Autio E, Thomas LDW (2014). Innovation ecosystems: Implications for innovation management. In: M Dodgson, N Philips, DM Gann (Eds), The Oxford handbook of innovation management. https:// doi.org/10.1093/oxfordhb/9780199694945.013.012

Bacon EC, William MD (2021) Deconstructing the ivory tower: identifying challenges of universityindustry ecosystem partnerships. RMS. https://doi.org/10.1007/s11846-020-00436-7

Banks J, Potts J (2010) Co-creating games: a co-evolutionary analysis. New Media Soc 12(2):253-270. https://doi.org/10.1177/1461444809343563

Baregheh A, Rowley J, Sambrook S (2009) Towards a multidisciplinary definition of innovation. Manag Decis 47(8):1323-1339. https://doi.org/10.1108/00251740910984578

Beliaeva T, Ferasso M, Kraus S, Damke EJ (2019) Dynamics of digital entrepreneurship and the innovation ecosystem: a multilevel perspective. Int J Entrep Behav Res 26(2):266-284. https://doi.org/10. 1108/IJEBR-06-2019-0397

Bossink BAG (2002) The development of co-innovation strategies: stages and interaction patterns in interfirm innovation. R\&D Management 32(4):311-320. https://doi.org/10.1111/1467-9310.00263

Bouncken RB, Kraus S (2021) Entrepreneurial ecosystems in an interconnected world: emergence, governance and digitalization. Rev Manag Sci. https://doi.org/10.1007/s11846-021-00444-1

Bouncken RB, Tiberius V (2021) Legitimacy processes and trajectories of co-prosumption services: insights from coworking spaces. J Serv Res. https://doi.org/10.1177/10946705211050208

Bouncken RB, Fredrich V, Kraus S, Ritala P (2020) Innovation alliances: balancing value creation dynamics, competitive intensity and market overlap. J Bus Res 112:240-247

Bouncken RB, Qiu Y, Sinkovics N, Kürsten W (2021) Qualitative research: extending the range with flexible pattern matching. RMS 15(2):251-273

Burger-Helmchen T, Cohendet P (2011) User communities and social software in the video game industry. Long Range Plan 44(5-6):317-343. https://doi.org/10.1016/j.lrp.2011.09.003

Carayannis EG, Campbell DFJ (2009) 'Mode 3' and 'Quadruple Helix': toward a 21st century fractal innovation ecosystem. Int J Technol Manage 46(3-4):201-234. https://doi.org/10.1504/IJTM.2009. 023374

Czakon W, Czernek-Marszałek K (2021) Competitor perceptions in tourism coopetition. J Travel Res 60(2):312-335. https://doi.org/10.1177/0047287519896011

Czakon W, Klimas P, Mariani M (2019) Behavioral antecedents of coopetition: a synthesis and measurement scale. Long Range Plan. https://doi.org/10.1016/j.lrp.2019.03.001

Dąbrowska J, Lopez-Vega H, Ritala P (2019) Waking the sleeping beauty : swarovski' s open innovation journey. R\&D Management. https://doi.org/10.1111/radm.12374

Dattee B, Alexy O, Autio E (2018) Maneuvering in poor visibility : how firms play the ecosystem game when uncertainty is high maneuvering in poor visibility: how firms play the ecosystem game when uncertainty is high. Acad Manag J 61(2):466-498. https://doi.org/10.5465/amj.2015.0869

de Gomes LAV, Facin ALF, Salerno MS, Ikenami RK (2018) Unpacking the innovation ecosystem construct: evolution, gaps and trends. Technol Forecast Soc Chang 136:30-48. https://doi.org/10. 1016/j.techfore.2016.11.009

Dedehayir O, Mäkinen SJ, Ortt RJ (2016) Roles during innovation ecosystem genesis: a literature review. Technol Forecast Soc Chang 136:18-29. https://doi.org/10.1016/j.techfore.2016.11.028

Del Bosco B, Chierici R, Mazzucchelli A (2020) User entrepreneurship in the video game industry: the role of communities. J Small Bus Enterp Dev 27(4):681-701. https://doi.org/10.1108/ JSBED-07-2019-0252

Durst S, Poutanen P (2013). Success factors of innovation ecosystems - Initial insights from a literature review. CO-CREATE 2013: The Boundary-Crossing Conference on Co-Design in Innovation (pp. 27-38).

Ernst H, Hoyer WD, Rübsaamen C (2010) Sales, marketing, and research-and-development cooperation across new product development stages: implications for success. J Mark 74:80-92. https://doi.org/ 10.1509/jmkg.74.5.080

Feijoó C (2012) An exploration of the mobile gaming ecosystem from developers' perspective. In: Zackariasson P, Wilson TL (eds) The video game industry. Formation, present state and futre. Routledge, New York

Ferasso M, Takahashi ARW, Gimenez FAP (2018) Innovation ecosystems : a meta-synthesis ecosystems. Int J Innovat Sci. https://doi.org/10.1108/IJIS-07-2017-0059 
Fereday J, Muir-Cochrane E (2006) Demonstrating rigor using thematic analysis: a hybrid approach of inductive and deductive coding and theme development. Int J Qual Methods 5(1):80-92. https:// doi.org/10.1177/160940690600500107

Fernandes AJ, Ferreira JJ (2021) Entrepreneurial ecosystems and networks: a literature review and research agenda. Rev Manag Sci. https://doi.org/10.1007/s11846-020-00437-6

Finfgeld-Connett D (2010) Generalizability and transferability of meta-synthesis research findings. J Adv Nurs 66(2):246-254. https://doi.org/10.1111/j.1365-2648.2009.05250.x

Galateanu E, Avasilcai S (2016) Framing the competitive behaviors of niche players: the electric vehicle business ecosystem perspective. Procedia Soc Behav Sci 221:342-351. https://doi.org/10.1016/j. sbspro.2016.05.124

Gawer A, Cusumano MA (2014) Industry platforms and ecosystem innovation. J Prod Innov Manag 31(3):417-433. https://doi.org/10.1111/jpim.12105

Geissdoerfer M, Bocken NM, Hultink EJ (2016) Design thinking to enhance the sustainable business modelling process-A workshop based on a value mapping process. J Clean Prod 135:1218-1232. https://doi.org/10.1016/j.jclepro.2016.07.020

Gioia DA, Corley KG, Hamilton AL (2013) Seeking qualitative rigor in inductive research: notes on the Gioia methodology. Organ Res Methods 16(1):15-31. https://doi.org/10.1177/1094428112452151

Graebner ME, Martin JA, Roundy PT (2012) Qualitative data: cooking without a recipe. Strateg Organ 10(3):276-284. https://doi.org/10.1177/1476127012452821

Granstrand O, Holgersson M (2020) Innovation ecosystems: a conceptual review and a new definition. Technovation 90-91:102098. https://doi.org/10.1016/j.technovation.2019.102098

Guion LA, Diehl DC, McDonald D (2011) Triangulation: establishing the validity of qualitative studies. EDIS 8:3-3

Gulati R, Puranam P, Tushman M (2012) Meta-organizational design: organizational and community contexts rethinking design in inter-organizational and community contexts. J Int Bus Stud 33(6):571-586. https://doi.org/10.1002/smj.1975/abstract

Hagen-Zanker J, Mallett R (2013) How to do a rigorous, evidence-focused literature review in international development: a guidance note. London: Overseas Development Institute. https://odi. org/en/publications/how-to-do-a-rigorous-evidence-focused-literature-review-in-internationaldevelopment-a-guidance-note/

Holgersson M, Granstrand O, Bogers M (2018) The evolution of intellectual property strategy in innovation ecosystems: uncovering complementary and substitute appropriability regimes. Long Range Plan 51(2):303-319. https://doi.org/10.1016/j.lrp.2017.08.007

Hoyer WD, Chandy R, Dorotic M, Krafft M, Singh SS (2010) Consumer cocreation in new product development. J Serv Res 13(3):283-296. https://doi.org/10.1177/1094670510375604

Hsieh HF, Shannon SE (2005) Three approaches to qualitative content analysis. Qual Health Res 15(9):1277-1288. https://doi.org/10.1177/1049732305276687

Humble ÁM (2009) Technique triangulation for validation in directed content analysis. Int J Qual Methods 8(3):34-51. https://doi.org/10.1177/160940690900800305

Inoue T, Nagayama S (2011) Strategic types and performance of niche-firms within business ecosystems: a study of the Japanese video game industry. Waseda Business Econ Stud 47:1-17

Inoue Y, Tsujimoto M (2017) New market development of platform ecosystems: a case study of the nintendo Wii. Technol Forecast Soc Chang. https://doi.org/10.1016/j.techfore.2017.01.017

Jucevičius G, Grumadaitė K (2014) Smart development of innovation ecosystem. Procedia Soc Behav Sci 156(April):125-129. https://doi.org/10.1016/j.sbspro.2014.11.133

Kapoor R, Furr N (2015) Complementaries and competition: unpacking the drivers of entrants' technology choices in the solar photovoltaic industry. Strateg Manag J 36:416-436. https://doi.org/ $10.1002 / \mathrm{smj}$

Kapoor R, Lee J (2013) Coordinating and competing in ecosystems: how organizational forms shape new technology investments. Acad Manage Proceed 34(3):274-296

Klimas P (2017) Current revenue (monetisation) models of video game developers. J Manage Financial Sci 10(28):119-136

Klimas P (2019) Relacje współtworzenia innowacji w ekosystemach. Kontekst ekosystemu gamingowego. C.H. Beck, Warszawa

Klimas P, Czakon W (2022) Species in the wild: a typology of innovation ecosystems. Rev Manag Sci 16:249-282. https://doi.org/10.1007/s11846-020-00439-4 
Koch S, Bierbamer M (2016) Opening your product : impact of user innovations and their distribution platform on video game success. Electron Mark 26:357-368. https://doi.org/10.1007/ s12525-016-0230-5

Koelsch LE (2013) Reconceptualizing the member check interview. Int J Qual Methods 12(1):168-179

Kraus S, Breier M, Dasí-Rodríguez S (2020) The art of crafting a systematic literature review in entrepreneurship research. Int Entrepreneurship Manage J 16(3):1023-1042

Le Roy F, Robert F, Hamouti R (2021). Vertical vs horizontal coopetition and the market performance of product innovation: An empirical study of the video game industry. Technovation, 102411.

Lee SM, Olson DL, Trimi S (2012) Co-innovation: convergenomics, collaboration, and co-creation for organizational values. Manag Decis 50(5):817-831. https://doi.org/10.1108/0025174121 1227528

Legault MJ, Weststar J (2015) The capacity for mobilization in project-based cultural work: a case of the video game industry. Canadian J Communi 40(2):203-221

Lin S, Yamakawa Y, Li J (2018) Emergent learning and change in strategy: empirical study of Chinese serial entrepreneurs with failure experience. International Entrepreneurship and Management Journal. https://doi.org/10.1007/s11365-018-0554-z

Lingo EL, Tepper SJ (2014) Looking Back, Looking Forward: Arts-Based Careers and Creative Work. Work Occup 40(4):337-363. https://doi.org/10.1177/0730888413505229

Marchand A, Hennig-Thurau T (2013) Value Creation in the Video Game Industry : Industry Economics, Consumer Bene fits, and Research Opportunities. J Interact Mark 27(3):141-157. https://doi.org/ 10.1016/j.intmar.2013.05.001

Mazzucato M, Robinson DKR (2018) Co-creating and directing Innovation Ecosystems? NASA's changing approach to public-private partnerships in low-earth orbit. Technol Forecast Soc Chang 136:166-177. https://doi.org/10.1016/j.techfore.2017.03.034

Mercan B, Göktaş D (2016) Components of Innovation Ecosystems : A Cross- Country Study Components of Innovation Ecosystems : A Cross-Country Study. Int Res J Financ Econ 76(76):102-112

Miles MB, Huberman AM (1994) Qualitative data analysis: an expanded source-book, 2nd edn. SagePublications, Thousand Oaks, California

Niemand T, Scott S, Kraus S, Oberreiner R, Puumalainen K (2021). Let the games begin: The relationship between video gaming and entrepreneurial mindsets. Journal of Small Business and Enterprise Development [early access]

Oh DS, Phillips F, Park S, Lee E (2016) Innovation ecosystems: A critical examination. Technovation 54:1-6. https://doi.org/10.1016/j.technovation.2016.02.004

Ozalp H, Cennamo C, Gawer A (2018) Disruption in platform-based ecosystems. J Manage Stud 55(7):1203-1241. https://doi.org/10.1111/joms.12351

Parmentier G, Mangematin V (2014) Orchestrating innovation with user communities in the creative industries. Technol Forecast Soc Chang 83:40-53. https://doi.org/10.1016/j.techfore.2013.03.007

Pattinson S, Nicholson J, Lindgreen A (2018) Emergent coopetition from a sensemaking perspective: A multi-level analysis. Ind Mark Manage 68:25-35. https://doi.org/10.1016/j.indmarman.2017.09. 005

Payne G, Williams M (2005) Generalization in qualitative research. Sociology 39(2):295-314. https:// doi.org/10.1177/0038038505050540

Phillips MA, Srai JS (2018) Exploring emerging ecosystem boundaries : defining ' the game.' Int J Innov Manag 22(8):1840012. https://doi.org/10.1142/S1363919618400121

Pilinkiene V, Maciulis P (2014) Comparison of different ecosystem analogies : the main economic determinants and levels of impact. Procedia Soc Behav Sci 156:365-370. https://doi.org/10.1016/j. sbspro.2014.11.204

Pombo-Juárez L, Könnölä T, Miles I, Saritas O, Schartinger D, Giesecke S (2017) Technological Forecasting \& Social Change Wiring up multiple layers of innovation ecosystems : Contemplations from Personal Health Systems Foresight. Technol Forecast Soc Chang 115:278-288. https://doi. org/10.1016/j.techfore.2016.04.018

Poor N (2013) Computer game modders 'motivations and sense of community: A mixed-methods approach. New Media Soc. https://doi.org/10.1177/1461444813504266

Prahalad CK (2004). The Co-Creation of Value. In R. N. Bolton (Ed.), The co-creation of value-invited commentaries on "Evolving to a new dominant logic for marketing". Journal of Marketing, 61(1):18-27.

Prahalad CK, Ramaswamy V (2004) Co-creation experiences: The next practice in value creation. J Interact Mark 18(3):5-14. https://doi.org/10.1002/dir.20015 
Ritala P, Almpanopoulou A (2017) In defense of 'eco' in innovation ecosystem. Technovation 60-61(February):39-42. https://doi.org/10.1016/j.technovation.2017.01.004

Rodzińska-Szary P, Bobrowski M, Socha M (2016). Kondycja polskiej branży gier. Raport 2015. [access: http://kreatywna-europa.eu/wp-content/uploads/2016/01/Raport-na-temat-kondycji-polskiejbranży-gier-wideo-1-1.pdf]

Rohrbeck R, Hölzle K, Gemünden HG (2009) Opening up for competitive advantage - How Deutsche Telekom creates an open innovation ecosystem. R\&D Management 39(4):420-430. https://doi.org/ 10.1111/j.1467-9310.2009.00568.x

Royer A, Bijman J (2009) Co-innovation, quality and institutions: A CoQA programme concepts exploration. Wageningen University, Wageningen, The Netherlands, Management Studies Group

Russell MG, Smorodinskaya NV (2018) Leveraging complexity for ecosystemic innovation. Technol Forecast Soc Chang 136:114-131. https://doi.org/10.1016/j.techfore.2017.11.024

Scaringella L, Radziwon A (2018) Innovation, entrepreneurial, knowledge, and business ecosystems : Old wine in new bottles? Technol Forecast Soc Chang 136:59-87. https://doi.org/10.1016/j.techf ore.2017.09.023

Schmalz M, Finn A, Taylor H (2014). Risk Management in Video Game Development Projects Risk Management in Video Game Development Projects. 47th Hawaii International Conference on System Sciences, 4325-4334. https://doi.org/10.1109/HICSS.2014.534

Schroth F, Häußermann JJ, Schraudner M (2018). Strategies for cooperation between companies and research organisations in innovation ecosystems - A case study of the German microelectronics and photonics industries. ISPIM Innovation Symposium, 1-13.

Scott S, Hughes M, Ribeiro-Soriano D (2021) Towards a network-based view of effective entrepreneurial ecosystems. Rev Manage Sci

Song J (2016) Innovation ecosystem : impact of interactive patterns, member location and member heterogeneity on cooperative innovation performance. Innovation 18(1):13-29. https://doi.org/10.1080/ 14479338.2016.1165624

Song XM, Thieme RJ, Xie J (1998) The impact of cross-functional joint involvement across product development stages: an exploratory study. J Prod Innov Manag 15(4):289-303. https://doi.org/10. $1111 / 1540-5885.1540289$

Spelmeyer M, Lingens B (2018). How young entrepreneurial companies orchestrate business ecosystems. Proceedings of the XXIX ISPIM Innovation Conference.

Stadler T, Chauvet JM (2018) New innovative ecosystems in France to develop the Bioeconomy. New Biotechnol 40:113-118. https://doi.org/10.1016/j.nbt.2017.07.009

Su YS, Zheng ZX, Chen J (2018) A multi-platform collaboration innovation ecosystem : the case of China. Management Decision 56(1):125-142

Sun SL, Chen VZ, Sunny SA, Chen J (2017) Venture capital as an ecosystem engineer for regional innovation in an emerging market. 2017 IEEE Technology and Engineering Management Society Conference. TEMSCON 2017:13-18. https://doi.org/10.1109/TEMSCON.2017.7998347

Sun SL, Zhang Y, Cao Y, Dong J, Cantwell J (2019) Enriching innovation ecosystems: The role of government in a university science park. Global Transitions 1:104-119. https://doi.org/10.1016/j.glt. 2019.05.002

Sunley P, Pinch S, Reimer S, Macmillen J (2008) Innovation in a creative production system : the case of design. Journal of Economic Geography 8:675-698. https://doi.org/10.1093/jeg/lbn028

Suri H (2011) Purposeful sampling in qualitative research synthesis. Qual Res J 11(2):63-75. https://doi. org/10.3316/QRJ1102063

Talmar M, Walrave B, Podoynitsyna KS, Holmström J, Romme AGL (2018) Mapping, analyzing and designing innovation ecosystems: The Ecosystem Pie Model. Long Range Plan 53(4):101850. https://doi.org/10.1016/j.1rp.2018.09.002

Thomas LDW, Autio E. (2020). Innovation ecosystems in management: An organizing typology. In: Oxford Encyclopedia of Business and Management. Oxford University Press.

Tschang FT (2005) Videogames As Interactive Experiential Products and Their Manner of Development. Int J Innov Manag 9(1):103-131. https://doi.org/10.1142/s1363919605001198

Tschang FT (2007) Balancing the Tensions Between Rationalization and Creativity in the Video Games Industry. Organ Sci 18(6):989-1005. https://doi.org/10.1287/orsc.1070.0299

Tschang FT, Szczypula J (2006) Idea Creation, Constructivism and Evolution as Key Characteristics in the Videogame Artifact Design Process. Eur Manag J 24(4):270-287. https://doi.org/10.1016/j. emj.2006.05.003 
Tsujimoto M, Kajikawa Y, Tomita J, Matsumoto Y (2018) A review of the ecosystem concept — Towards coherent ecosystem design. Technol Forecast Soc Chang 136:49-58. https://doi.org/10.1016/j.techf ore.2017.06.032

Valkokari K (2015). Business, Innovation, and Knowledge Ecosystems: How They Differ and How to Survive and Thrive within Them. Technology Innovation Management Review, 5(8), 17-24. https://doi.org/10.22215/timreview/919

van Blokland WB, Verhagen WJ, Santema SC (2008) The effects of co-innovation on the value-time curve: quantitative study on product level. J Bus Mark Manag 2(1):5-24. https://doi.org/10.1007/ s12087-007-0020-7

Vargo SL (2009) Toward a transcending conceptualization of relationship : a service-dominant logic perspective. Journal of Business \& Industrial Marketing 24(5/6):373-379. https://doi.org/10.1108/ 08858620910966255

Vargo SL, Lusch RF (2004) The four service marketing myths: Remnants of a goods-based, manufacturing model. J Serv Res 6(4):324-335

Vargo SL, Lusch RF (2011) It's all B2B ... and beyond: Toward a systems perspective of the market. Ind Mark Manage 40(2):181-187. https://doi.org/10.1016/j.indmarman.2010.06.026

Vargo SL, Wieland H, Akaka MA (2015) Innovation through institutionalization: A service ecosystems perspective. Ind Mark Manage 44:63-72. https://doi.org/10.1016/j.indmarman.2014.10.008

Walrave B, Talmar M, Podoynitsyna KS, Romme AGL, Verbong GP (2018) A multi-level perspective on innovation ecosystems for path-breaking innovation. Technol Forecast Soc Change 136:103-113

Weil HB, Sabhlok VP, Cooney CL (2014) The dynamics of innovation ecosystems: a case study of the US biofuel market. Energy Strategy Rev. https://doi.org/10.1016/j.esr.2014.07.005

Weststar J (2015) Understanding video game developers as an occupational community. Inf Commun Soc 18(10):1238-1252. https://doi.org/10.1080/1369118X.2015.1036094

Wu J, Ye R, Ding L, Lu C, Euwema M (2018) From "transplant with the soil" toward the establishment of the innovation ecosystem: a case study of a leading high-tech company in China. Technol Forecast Soc Chang 136:222-234. https://doi.org/10.1016/j.techfore.2017.06.001

Xu G, Wu Y, Minshall T, Zhou Y (2018) Exploring innovation ecosystems across science, technology, and business: a case of 3D printing in China. Technol Forecast Soc Chang 136:208-221. https:// doi.org/10.1016/j.techfore.2017.06.030

Yaghmaie P, Vanhaverbeke W (2019) Identifying and describing constituents of innovation ecosystems A systematic review of the literature. EuroMed J Bus. https://doi.org/10.1108/EMJB-03-2019-0042

Zackariasson P, Wilson TL (2010) Paradigm shifts in the video game industry. Competitiveness Rev: an Int Business J 20(2):139-151. https://doi.org/10.1108/10595421011029857

Zhang JZ, Watson IV GF (2020) Marketing ecosystem: an outside-in view for sustainable advantage. Indust Market Manage 88:287-304

Publisher's Note Springer Nature remains neutral with regard to jurisdictional claims in published maps and institutional affiliations. 